\title{
Bestuursrechtspraak (ooit) aan de vooravond van een hervorming?
}

\author{
Kaat Leus*
}

\section{Bestuursrechtspraak: quo vadis?}

Het is niet eenvoudig een Belgisch preadvies dat bondig en helder zou moeten zijn, te wijden aan 'bestuursrechtspraak' in de ruime betekenis van de hoogste rechtscolleges. Beperken we ons, wat België betreft, tot de administratieve rechtscolleges en in het bijzonder tot de Raad van State, afdeling bestuursrechtspraak, hetgeen we hierna toch zullen doen, dan komt dat neer - dat moet toegegeven worden - op het geven van een onvolledig beeld. De rechtsbescherming tegen de (bestuurs)overheid is In België gekenmerkt door een jurisdictioneel pluralisme. Het Belgische stelsel is geëvolueerd, aldus C. BERX, van een gecorrigeerd monisme naar een stevig verankerd pluralisme. ${ }^{\mathrm{I}}$

Inderdaad, geschillen beslechten omtrent subjectieve (burgerlijke en politieke) rechten behoort, krachtens de artikelen $144^{2}$ en $145^{3}$ van de Grondwet, in beginsel de gewone justitiële rechter (lees: de rechterlijke macht) toe zowel in eerste aanleg als in beroep evenals de daarmee verbonden voorzieningen in cassatie waarover het Hof van Cassatie zich buigen zal. De fiscale (bestuurs)rechtspraak is (veelal), alvast waar het de jurisdictionele beroepen en de voorzieningen in cassatie betreft, een zaak van de gewone rechter. Hetzelfde geldt voor talrijke andere betwistingen inzake o.m. overheidspensioenen, leefloon, betwistingen omtrent de interpretatie, uitvoering en beëindiging van (administratieve) contracten met de overheid, (on)rechtmatige overheidsdaad, (de gerechtelijke fase bij) onteigeningen, enz. Reeds wat het sociaal contentieux betreft heeft de wet van ro oktober I $_{967}$ houdende het Gerechtelijk Wetboek, een regeling tot stand gebracht waarbij de bevoegdheid tot het beslechten van alle desbetreffende geschillen in eerste aanleg opgedragen is aan de arbeidsrechtbanken, in hoger beroep aan de arbeidshoven en in cassatie aan de sociale kamer van het Hof van Cassatie. Kortom, het is gepast eraan te herinneren dat de 'gewone' rechter in te talrijk om op te sommen gevallen van het subjectief contentieux de rechter is die instaat voor de rechtsbescherming tegen de overheid.

* Kaat Leus is advocaat en hoofddocent Bestuursrecht.

I. C. BERX, Rechtsbescherming van de burger tegen de overheid. Een analyse van het systeem van administratieve rechtspraak in België, Antwerpen-Groningen, Intersentia Rechtswetenschappen, 2000, p. 8I.

2. Artikel I44 van de Grondwet bepaalt dat geschillen over burgerlijke rechten bij uitsluiting tot de bevoegdheid van de rechtbanken behoren.

3. Artikel I45 van de Grondwet stelt dat geschillen over politieke rechten tot de bevoegdheid van de rechtbanken behoren, behoudens de bij de wet gestelde uitzonderingen. 
Het voorgaande neemt echter niet weg dat talrijke betwistingen met het bestuur niet voor de rechterlijke macht ${ }^{4}$ worden gebracht maar worden beslecht door de in de artikelen I6o en I6I van de Grondwet bedoelde administratieve rechtscolleges en, in het bijzonder de Raad van State, afdeling bestuursrechtspraak.

De (uitdrukkelijk toegewezen) rechtsmacht van de administratieve rechtscolleges in het kader van het subjectief contentieux (betwistingen betreffende politieke rechten) vindt zijn grondslag in artikel I45 (en I46) van de Grondwet en een op grond daarvan uitgevaardigde specifieke wet. Het volstaat te denken aan (bepaalde aspecten van) betwistingen inzake (lokale en provinciale) verkiezingen, betwistingen op het economisch vlak (mededinging, e.d.m.) die, omdat de beslechting ervan (minstens in eerste aanleg) is opgedragen aan administratieve rechtscolleges, allicht (zie hierna) zijn te beschouwen als politieke rechten.

Voor een invulling van het begrip 'politieke rechten' gold in wezen het zgn. organiek criterium. Concreet komt het erop neer dat, om uit te maken of zij bevoegd zijn, de hoven en rechtbanken slechts dien(d)en te onderzoeken in de eerste plaats of het gaat om een subjectief recht en daarna of een wet de daarop betrekking hebbende geschillen niet aan een administratief rechtscollege heeft opgedragen. Die organieke benadering werd evenwel een aantal jaren geleden in ruime mate afgewezen door het Grondwettelijk Hof. Het Grondwettelijk Hof verklaarde zich immers bevoegd, teneinde (gebeurlijke) willekeur te sanctioneren, te onderzoeken of de wetgever de in het geding betrokken rechten wel terecht als politieke rechten had beschouwd. Dergelijke controle brengt evenwel mee dat niet een organiek maar een inhoudelijk criterium wordt betrokken op de tweedeling burgerlijke - politieke rechten waarbij is te onderzoeken of de overheid optreedt in de uitoefening van een functie die in een dergelijke verhouding staat tot de prerogatieven van het openbaar gezag van de Staat, dat zij zich buiten de werkingssfeer bevindt van de gedingen van burgerlijke aard in de zin van artikel $\mathrm{I} 44$ van de Grondwet, ${ }^{5}$ hetgeen voorwaar niet altijd een gemakkelijke beoordeling zal zijn. Aldus werd geoordeeld dat de sanctie bestaande in het verbod tot terugbetaling van de door een zorgverlener verstrekte geneeskundige verzorging haar grondslag vindt in de verstoring van de goede werking van de verplichte ziekteverzekering. Een betwisting omtrent een dergelijk verbod betreft de beoordeling van de naleving door de zorgverlener van zijn verplichtingen in zoverre hij meewerkt aan de realisatie van een openbare dienst zodat het kan worden beschouwd als een betwisting omtrent een politiek recht.

Hoe dan ook, wanneer de Raad van State uitspraak moet doen over een subjectief beroep d.w.z. een beroep tot nietigverklaring van een administratieve beslissing in betwiste zaken, zijnde van een beslissing van een rechtscollege dat bij wet is opgericht om

4. Hoofdstuk VI van de Grondwet.

5. Arbitragehof nr. I4/97 van I8 maart I997, R.W. I996-I997, p. I423-I428, noot A. ALEN; Arbitragehof nr. I33/200I, 30 oktober 200I; Arbitragehof 26/2002, 30 januari 2002; Arbitragehof nr. 23/ 2003, I2 februari 2003 h; B. BLERO, 'Les droits subjectifs, les droits civils et les droits politiques dans la Constitution. Observations relatives à l'arrêt de la Cour d'Arbitrage Nr. I4/97 du I8 mars I997', A.P.T., I997, p. 233-279; Over de teloorgang van het organiek criterium, zie nog C. Berx, 0.c., 2000, p. 96; J. Vande Lanotte en G. Goedertier, Inleiding tot het publiek recht, II, Overzicht publiek recht, Brugge, Die Keure, 2003, nr. I2I4, p. 783-784. 
geschillen over politieke rechten te beslechten is zijn bevoegdheid gebaseerd op de artikelen 145 en 146 van de Grondwet.

Wanneer daarentegen het beroep tot nietigverklaring niet is gericht tegen een administratieve beslissing in betwiste zaken maar, in het kader van het objectief contentieux, tegen een uitvoerbare griefhoudende (en betwiste) handeling of reglement van een administratieve overheid, waarbij deze op haar wettigheid of, beter, rechtmatigheid wordt getoetst en erga omnes door middel van één arrest kan worden geschorst en/of vernietigd wegens schending van hetzij substantiële, hetzij op straffe van nietigheid voorgeschreven vormen, overschrijding of afwending van macht, is artikel I46 van de Grondwet de enige basis voor de bevoegdheid van de Raad van State. Ook de opdeling tussen het subjectief en objectief contentieux, liefst via de notie '(eenzijdig) administratieve rechtshandeling', is verre van evident. Hoe zit het in dat verband trouwens met de beoordeling of sprake is, al dan niet, van het bestaan van een 'subjectief recht', de invulling van noties als 'declaratieve' en 'constitutieve bestuurshandelingen', de glijdende lijn tussen 'gebonden' versus 'discretionaire' bestuursbevoegdheden. Is het nog langer verantwoord, gegeven de huidige stand van het recht en de actuele invulling van de rechtsstaat, dit (strikt voorgestelde) onderscheid tussen het zgn. subjectieve' en 'objectieve' contentieux te handhaven, inzonderheid waar het individuele bestuurshandelingen betreft, evenals hun toewijzing aan verschillende rechtsmachten?

Wat er ook van zij, de voorbije decennia is geregeld gewezen op de voor - respectievelijk nadelen van het jurisdictioneel monisme respectievelijk pluralisme met, elk, zijn mede - en tegenstanders. Geregeld ook wordt de beleidsmatige vraag gesteld of de bestuursrechtspraak niet aan een fundamentele hervorming toe is waarbij, met het oog op een verbetering van de rechtsbescherming, aan verschillende, uiteenlopende opties wordt gedacht gaande van een herstructurering en consequent onderbrenging van het (volledige) bestuurlijk contentieux bij de gewone hoven en rechtbanken hetzij binnen de rechtbanken van eerste aanleg dan wel (steeds binnen de rechterlijke macht) de creatie van administratieve rechtbanken dan wel een grondige herstructurering van de bestuursrechtspraak na te streven door het consequent invoeren buiten de rechterlijke macht van administratieve rechtbanken 'onder' de Raad van State waarbij de administratieve rechtscolleges bedoeld in de artikelen I6o en I6I van de Grondwet de bestuurs geschillen voor hun rekening nemen met inbegrip van de mogelijkheid tot het volwaardig verlenen van rechtsherstel inclusief de toewijzing van eventuele vorderingen tot schadeloosstelling, waarbij de Raad van State voorts ook bevoegd blijft voor de vernietigingsberoepen gericht tegen reglementaire besluiten terwijl deze vernietigingsbevoegdheid wat de reglementaire besluiten betreft in de eerste optie bijvoorbeeld zou kunnen worden ondergebracht bij het Grondwettelijk Hof.

Veelgehoorde (doch niet exhaustief) argumenten voor een fundamentele hervorming, in de ene of andere zin, zijn het streven naar eenheid in jurisprudentie, helderheid qua toegang tot de rechter voor de burger, één rechtsingang voor alle geschillen met de overheid, specialisatie en deskundigheid of, nog, de hoop dat met een grondige hervorming een oplossing kan worden gegeven aan de problematiek van het wegwerken van de achterstand bij de Raad van State die zich dan wanneer deze van het subjectief contentieux zou worden 'verlost' zich zou kunnen concentreren op de 
belangrijke principekwesties zoals o.m. het vernietigen van onwettige reglementaire besluiten.

In welke richting het uiteindelijk zal evolueren is niet of moeilijk te voorspellen al zullen sommigen beweren dat, in het licht van enige recente evoluties, valt te verwachten dat het jurisdictioneel pluralisme zal worden behouden en (het contentieux bij) de Raad van State zal worden 'afgeslankt' naar onderen toe door de creatie van administratieve rechtbanken van eerste aanleg hetgeen overigens kan zonder grondwetswijzigingen. De recente oprichting van o.m. de provinciale Raden voor Verkiezingsbetwistingen, de Raad voor Vreemdelingenbetwistingen of, nog, de Raad voor Studievoortgangbetwistingen zouden alvast in die richting wijzen waarbij de Raad van State (nog) optreedt - met volle rechtsmacht of als administratieve cassatierechter. Andere (recente) hervormingen wijzen dan weer in een (de facto) beperking van het jurisdictioneel pluralisme, inzonderheid in de economische sector (zie bijvoorbeeld art. 28 van de wet van ro juni 2006 tot oprichting van een Raad voor de mededinging resp. art. 75 van de wet van I5 september 2006 tot bescherming van de economische mededinging, gecoördineerd op I5 september 2006) waar althans wat de jurisdictionele beroepsinstantie betreft, de beslechting van geschillen toch worden ondergebracht, minstens in de fase van het hoger beroep, bij de rechterlijke macht. Nog in die richting wijzen de hervormingen in het fiscaal contentieux dat volledig onttrokken is aan de bestendige deputatie en de directeur der belastingen ten voordelen van de burgerlijke rechter. Deze 'gerichte' oplossingen voor een 'bepaald' probleem zouden kwade tongen ertoe kunnen brengen te stellen, wat al deze wetgevende tussenkomsten betreft, dat er op heden geen globaal, weldoordacht en consequent justitieel beleid achter zit. ${ }^{6}$

De meest recente hervorming is deze ingevoerd met de wet van 5 september 2006 tot hervorming van de Raad van State en tot oprichting van een Raad voor Vreemdelingenbetwistingen. Hoewel niet revolutionair, wordt deze hervorming belangrijk geacht niet in het minst omdat ervan wordt gehoopt (terecht of ten onrechte hetgeen enkel de toekomst kan en zal uitwijzen) dat hierdoor de achterstand in de rechtsbedeling bij de Raad van State wordt weggewerkt en/of (?) onder controle gehouden en, anderzijds, de procedures met betrekking tot de vreemdelingen te optimaliseren om te voorzien in een deugdelijke jurisdictionele bescherming. ${ }^{7}$ Met deze wet werden verscheidene maatregelen doorgevoerd die steunen op een aantal hoofdlijnen. Vooreerst beoogt de wet (I.) structurele en organisatorische maatregelen bij de Raad van State door te voeren om de werkwijze van de Raad van State te verbeteren waaronder technieken van modern management zoals het invoeren van een mandatenstelsel voor bepaalde ambten, het invoeren van een evaluatiestelsel en dies meer. Daarnaast vindt een (fundamentele) hervorming van de bevoegdheid van de Raad van State plaats in het kader van de geschillenbeslechting inzake vreemdelingenzaken (d.w.z. de schorsing - en vernietigingsbevoegdheid inzake beroepen gericht tegen individuele beslissingen genomen met toepassing van de wetten betreffende de toegang tot het grondgebied, het verblijf, de vestiging en de verwijdering van vreemdelingen)

6. Voor een bondig overzicht van gesuggereerde opties: C. BERX, o.c., p. 595 e.v.

7. Parl. St., Kamer, 2005-2006, stuk nr. 2479/001, p. 262. 
doordat (2.) een nieuw administratief rechtscollege wordt opgericht met name de Raad voor Vreemdelingenbetwisting zodat de rol van de Raad van State in deze materie wordt beperkt tot deze van administratieve cassatie hetgeen een zoveelste uiting zou kunnen zijn voor een (niet - uitgesproken) beleidskeuze te opteren voor een hervorming van de administratieve rechtspraak door de invoering van administratieve rechtbanken 'onder' de Raad van State. Ook de afschaffing van een aantal andere bevoegdheden (o.m. de adviesbevoegdheid van de afdeling bestuursrechtspraak in niet - betwiste zaken) zouden moeten kunnen leiden tot een verlichting van de werklast. Ten slotte, niet onbelangrijk en evenzeer vanuit een oogpunt van het niet over - bevragen van de Raad van State, voert de wet op veralgemeende wijze een 'toelaatbaarheidsprocedure' in in het kader van de administratieve cassatiebevoegdheid van de Raad van State ten aanzien van de beslissingen van administratieve rechtscolleges, ongeacht de geschillen waarin de laatstgenoemden moeten optreden. Die laatste hervorming komt verderop meer specifiek aan bod.

\section{Taakomschrijving van de Raad van State, afdeling bestuursrechtspraak: algemeen}

Als hoogste administratieve rechtscollege heeft de Raad van State de taak om de (grond)wettigheid cq. rechtmatigheid van (reglementaire en individuele) bestuurshandelingen te controleren, de rechtsbescherming te waarborgen van de burger tegen de overheid en geschillen (definitief) te beslechten. Hierbij zal de Raad van State rekening dienen te houden met de mate waarin de overheid over een beoordelings- en/of beleidsvrijheid beschikt en zal een belangenafweging moeten gebeuren tussen het algemeen en het individueel belang. De afdeling bestuursrechtspraak van de Raad van State heeft uiteenlopende jurisdictionele taken ${ }^{8}$ waarbij, zoals hiervoor is aangegeven, een onderscheid kan worden gemaakt tussen het zgn. 'subjectief' en het 'objectief' contentieux.

Het subjectief contentieux bij de Raad van State omvat, enerzijds, geschillen over (subjectieve) politieke rechten in de rechtsbetrekkingen tussen burger en bestuur waarbij de afdeling bestuursrechtspraak van de Raad van State uitspraak doet ten gronde met volle rechtsmacht zoals, bijvoorbeeld, over sommige geschillen in verband met de gemeentekieswet en, anderzijds, de administratieve cassatieberoepen waarbij uitspraak wordt gedaan over beslissingen ('in betwiste zaken') van administratieve rechtscolleges maar waar niet over de grond van de zaak wordt geoordeeld. Deze rechtsmacht beslaat een afgebakend deelgebied van het bestuursrecht.

Het objectief contentieux omvat beroepen tot schorsing en/of nietigverklaring tegen de 'akten en reglementen van de onderscheiden administratieve overheden'. Door de nietigverklaring (al dan niet voorafgegaan door een schorsing) worden onrechtmatige bestuurshandelingen erga omnes uit de rechtsorde verwijderd.

8. De vroegere niet-jurisdictionele taken zijn ofwel opgeheven ofwel overgedragen. 
De Raad van State heeft ter zake wat de vernietigingsbevoegdheid van individuele bestuursbeslissingen betreft, geen monopolie. Bij wijze van voorbeeld kan worden gewezen op de Raad voor betwistingen inzake studievoortgangsbeslissingen die een vernietigingsbevoegdheid heeft wanneer zij zich uitspreekt over de beroepen die door studenten worden ingesteld tegen examen(tucht)beslissingen of de Raad voor Vreemdelingenbetwistingen die een schorsings- en vernietigingsbevoegdheid heeft met betrekking tot individuele beslissingen in het vreemdelingenrecht. De afdeling bestuurrechtspraak van de Raad van State spreekt zich uit in tal van deelgebieden van het bestuursrecht zoals het ambtenarenrecht, het stedenbouw- en ruimtelijk ordeningsrecht, het milieurecht, het economisch bestuursrecht, e.a.

De bevoegdheid van de Raad van State om bij wijze van arrest uitspraak te doen over de beroepen tot nietigverklaring ingesteld tegen de akten en reglementen van de onderscheiden administratieve overheden en over de administratieve (cassatie)beroepen ingesteld tegen de door de administratieve rechtscolleges in laatste aanleg gewezen beslissingen in betwiste zaken zijn veruit de belangrijkste. Deze bevoegdheid maakt van de Raad van State - onder voorbehoud van wat hoger is gezegd - zowel de rechter over de machtsoverschrijding in al haar vormen, als de (gewone) cassatierechter over administratieve rechtscolleges. In het eerste geval gaat het om een objectief contentieux waarbij een handeling van het actief bestuur wegens machtsoverschrijding uit de rechtsordening wordt geweerd; in het tweede geval neemt de Raad van State als cassatierechter kennis van deze vernietigingsberoepen in het subjectief contentieux.

In beide gevallen is de rechtspleging voor de afdeling bestuursrechtspraak van de Raad van State autonoom en wordt deze geregeld in afzonderlijke wetten en uitvoeringsbesluiten. De basisteksten zijn de gecoördineerde wetten van I2 januari I973 op de Raad van State (hierna: 'de R.v.St.-wet') ${ }^{9}$ en het Regentsbesluit van 23 augustus I948 tot regeling van de rechtspleging voor de afdeling bestuursrechtspraak van de Raad van State (hierna: 'het procedurereglement'). ${ }^{\text {IO }}$ Slechts aanvullend zal een beroep worden gedaan op het gemeen recht vervat in het Gerechtelijk Wetboek, evenwel steeds rekening houdend met het eigen karakter van de procesvoering voor de Raad van State. ${ }^{\text {II }}$ Bijgevolg kenmerkt de rechtspleging voor de Raad van State zich door haar inquisitoriale, schriftelijke en summiere aard ${ }^{\mathrm{I} 2}$ en door het eigen karakter van de opdracht van het Auditoraat. ${ }^{\mathrm{I3}}$

Dit preadvies spitst zich voornamelijk toe op het beroep tot nietigverklaring tegen akten en reglementen van administratieve overheden (IV.) omdat dit thans kwantitatief de belangrijkste taak lijkt van de Raad van State. Daarnaast zal kort worden ingegaan op de schorsingsbevoegdheid van de Raad van State en de daaraan eigen procedurele karakteristieken (V.). Vervolgens zal worden stil gestaan bij de (administra-

9. B.S. 2 I maart 1973.

Io. B.S. 23 augustus 1948 .

II. S. De Taeye, 'Procedures voor de Raad van State', in X, Recht en Praktijk, Mechelen, Kluwer, 2003, p. 38-39.

I2. S. De Taeye, l.c., p. 39 .

13. A. WIRTGEN, 'Raad van State. Afdeling Administratie. Middelen en het ambtshalve aanvoeren van middelen in het bijzonder', in X. (ed.), Administratieve rechtsbibliotheek, Brugge, Die Keure, 2003, p. 3 . 
tieve) cassatieberoepen tegen beslissingen van administratieve rechtscolleges omdat deze belangrijker lijken te worden in het licht van de recente hervormingen (punt VI.). Ten slotte worden een aantal bijkomende observaties gemaakt (punt VII.).

\section{Kenmerken van de rechtspleging voor de afdeling bestuursrechtspraak van de Raad van State}

De rechtspleging voor de afdeling bestuursrechtspraak is inquisitoriaal van aard met als gevolg dat de leiding ervan bij de Raad van State zelf berust en niet bij de gedingvoerende partijen. ${ }^{\mathrm{I}}$ Redenen hiervoor zijn onder meer de ongelijke positie tussen de burger, enerzijds, en het bestuur met zijn eenzijdige gezagsbevoegdheid anderzijds, evenals de afweging die gemakt moet worden tussen het individuele en het algemene belang. Door de leiding van de procedure aan de Raad van State zelf toe te vertrouwen, wordt haar doel, met name, de wettigheid van de administratieve bestuurshandelingen waarborgen, vergemakkelijkt.

Bijgevolg kan de Raad van State onder meer op eigen initiatief onderzoeksverrichtingen bevelen, rechtstreeks briefwisseling voeren met alle administratieve overheden, zelf instaan voor de mededeling van ontvangen verzoekschriften en memories, zij spreekt zich uit over afstand van geding, verzoeken tot tussenkomst, ... ${ }^{\text {5 }}$

De rechtspleging is schriftelijk wat inhoudt dat de partijen al hun middelen schriftelijk moeten uiteenzetten én ontwikkelen. Tijdens de zitting krijgen de partijen of hun advocaten de gelegenheid om hun middelen mondeling toe te lichten doch zij mogen geen andere middelen inroepen dan deze uit het verzoekschrift en de memories. ${ }^{16}$ Vooral in de vernietigingsprocedure - méér dan in de schorsingsprocedures waarin meer ruimte wordt gelaten om de feiten toe te lichten - waar memories van antwoord en wederantwoord of toelichtende en laatste memories voorzien zijn, is het mondelinge debat minimaal. ${ }^{17}$ In de schorsingsprocedure, is geen processtuk voorzien waarin verzoekende partij nog kan repliceren op de nota van verwerende partij, waardoor, zoals gezegd, de debatten soms langer kunnen duren. Ook hier echter blijft de rechtspleging in essentie schriftelijk en zullen de middelen, alsook het moeilijk te herstellen ernstig nadeel, of in voorkomend de redenen voor een beroep bij uiterst dringende noodzakelijkheid, reeds in het inleidend verzoekschrift worden uiteengezet. ${ }^{18}$

Door de meest recente wijzigingen aan de vernietigingsprocedure ${ }^{\mathrm{I} 9}$ is het waarschijnlijk of mag, minstens, worden verhoopt, dat het ter zitting gevoerde contradictoir debat aan belang zal winnen. Vóór de inwerkingtreding op I juni 2007 van een aantal gewijzigde bepalingen van het procedurereglement werd het verslag van de

I4. A. Mast, J. Dujardin, M. Van Damme, J. Vande Lanotte, Overzicht van het Belgisch Administratief Recht, Mechelen, Kluwer, 2006, p. IIog.

I5. A. Mast, J. Dujardin, M. Van Damme, J. Vande Lanotte, o.c., p. IIog.

I6. A. Mast, J. Dujardin, M. Van Damme, J. Vande Lanotte, o.c., p. IIIo.

I7. S. De Taeye, o.c., p. 4I.

I8. S. De Taeye, o.c., p. 4I-42.

I9. Wet vanis september 2006 tot hervorming van de Raad van State en tot oprichting van een Raad voor Vreemdelingenbetwistingen (B.S. 6 oktober 2006). 
auditeur immers altijd eerst ter kennis gebracht van de verzoekende partij. Evenwel zal volgens de huidige regeling het auditoraatsverslag tegelijk worden betekend aan alle partijen, zodat alle partijen, en voortaan dus ook de tussenkomende partij, beschikken over een termijn van dertig dagen om hun verzoek tot voortzetting van de procedure en hun laatste memorie in te dienen. ${ }^{20}$ Bijgevolg zal verwerende partij nog niet kunnen antwoorden op de laatste memorie van verzoekende partij en zal het mondeling debat eveneens (moeten) worden aangewend om hierop te repliceren.

De rechtspleging is summier omdat een eenvoudig verzoekschrift volstaat om de zaak aanhangig te maken bij de Raad van State. Alle processtukken worden aangetekend verstuurd aan de Raad van State. De termijnen om processtukken over te maken zijn kort en bovendien vervaltermijnen die bijgevolg niet voor verlenging vatbaar zijn. De partijen kunnen zich laten vertegenwoordigen door een advocaat. ${ }^{2 I}$

De in 1948 beoogde snelle afhandeling, waarbij men zich ontdoet van enig overdreven formalisme lijkt in de praktijk nochtans moeilijk te handhaven, getuige hiervan zijn de jarenlange procedures en het toegenomen formalisme. De recente wijzigingen betreffende de Raad van State omvatten een aantal maatregelen om de gerechtelijke achterstand werk te werken. Eén van de maatregelen om de Raad van State te ontlasten is de oprichting van de Raad voor Vreemdelingenbetwistingen. De recente oprichting van andere administratieve rechtscolleges zoals de Raad voor betwistingen inzake studievoortgangsbeslissingen of, nog, de hervorming van het lokale verkiezingscontentieux met de oprichting van een onafhankelijke Raad voor Verkiezingsbetwistingen leidt ook tot een vermindering van het aantal procedures bij de Raad van State.

Evenwel neemt het formalisme in de procedures toe. Deze trend, die reeds merkbaar was in vroegere rechtspraak, ${ }^{22}$ lijkt nog te worden versterkt met de recente wijzigingen.

\section{I De vernietigingsbevoegdheid van het objectief contentieux}

\subsubsection{Doel en toepassingsvoorwaarden van het objectief vernietigingsberoep}

Onverminderd de andere middelen waarover de rechtsonderhorige beschikt om het bestuur aan de wet te houden, blijft het beroep tot vernietiging wegens machtsoverschrijding een efficiënt middel om onwettige bestuurshandelingen te bestrijden zowel omdat op die wijze wordt bekomen dat de onwettige rechtshandeling met één enkel rechtsgeding erga omnes uit de juridische ordening kan worden geweerd, en daarenboven omdat met het vernietigingsarrest in beginsel - ook op het vlak van een eventuele daaropvolgende burgerrechtelijke procedure met het oog op het herstel

20. Verslag aan de Koning bij het Koninklijk besluit van 25 april 2007 tot wijziging van diverse besluiten betreffende de procedure voor de afdeling bestuursrechtspraak van de Raad van State.

2I. S. De Taeye, o.c., p. 42.

22. R.v.St., Gonry, nr. 70.I49, Io december I997: de betekening van de betreden beslissing moet naast de termijn eveneens vermelden dat het beroep moet worden ingediend per aangetekend schrijven, zoniet begint de beroepstermijn niet te lopen. 
van de hierdoor veroorzaakte schade - de fout in de zin van artikel 1382 B.W. is bewezen. Of daarmee ook is gezegd dat het het geschiktste middel is, is gegeven de achterstand, niet meteen duidelijk. Het is dan ook goed te kunnen vaststellen dat 'de overheid' belangrijke inspanningen levert om die achterstand weg te werken. Zo zijn er de hoger vermelde inspanningen van de wetgever (zie hoger) ter ontlasting van de Raad van State, evenals deze van de Raad van State zelf. Meer en meer geeft de afdeling Bestuursrechtspraak in zijn jurisprudentie duidelijk aan hoe de rechtsingangen best worden gehanteerd of juist niet gehanteerd. Dat is nuttig om obstructie te voorkomen en te bewerkstelligen dat de procedures (bijvoorbeeld de gewone schorsingsprocedure of de schorsingprocedure bij uiterst dringende noodzakelijkheid) worden gehanteerd waarvoor ze moeten worden gehanteerd. Door die stroomlijning kan worden bewerkstelligd dat de 'gewone' vernietigingsprocedures niet worden benadeeld door het te pas of te onpas aanwenden van schorsingsprocedures. Dergelijke tendens is bijvoorbeeld merkbaar in de jurisprudentie betreffende de overheidsopdrachten. ${ }^{23}$

De Raad van State neemt kennis van schorsing - en vernietigingsberoepen tegen eenzijdige administratieve rechtshandelingen van Belgische administratieve overheden. Het zijn de rechtspraak en de rechtsleer die deze begrippen hebben ontwikkeld. ${ }^{24}$

Zowel het begrip 'administratieve overheid' als 'aanvechtbare (want griefhoudende) administratieve rechtshandeling' geeft geregeld aanleiding tot discussie. Dat is de voorbije jaren zeker zo geweest wat het begrip 'administratieve overheid' betreft hetgeen een wezensbegrip is voor de bevoegdheidsafbakening van de Raad van State en meermaals aanleiding gaf tot een bevoegdheidsconflict dat ter beslechting aan het Hof van Cassatie werd voorgelegd. Een en ander heeft ertoe geleid dat, in de loop der jaren, aan bepaalde elementen om uit te maken of een organisme kwalificeert als een (administratieve) overheid, een andere betekenis is gehecht of dat bepaalde elementen zijn aangevuld met andere, waardoor de initiële elementen (zoals 'opgericht door de overheid) aan belang lijken te hebben ingeboet. Vandaag schijnt zoniet uitsluitend dan toch fundamenteel te zijn dé vraag of al dan niet sprake is van eenzijdige gezagsbevoegdheid ten aanzien van derden. ${ }^{25}$

Ook de wetgever heeft gaandeweg, en recentelijk nog naar aanleiding van een arrest van het Grondwettelijk Hof, ${ }^{26}$ de R.v.St.-wet dienen te verduidelijken ${ }^{27}$ door te stellen dat ook akten en reglementen van de wetgevende vergaderingen of van hun organen daarbij inbegrepen de ombudsmannen ingesteld bij deze assemblees, van het Rekenhof en van het Grondwettelijk Hof, van de Raad van State en de administratieve rechtscolleges evenals van organen van de rechterlijke macht en van de

23. R.v.St., Van Vooren, nr. I27.069, I3 januari 2004; R.v.St., NV Antwerpse Bouwwerken e.a., nr. I65.404, 30 november 2006.

24. A. Mast, J. Dujardin, M. Van Damme, J. Vande Lanotte, o.c., p. 972.

25. Zie o.m. F. Van den Driessche, 'De invulling van het begrip administratieve overheid na de arresten Gimvindus en BATC van het Hof van Cassatie', R.W., 2000-200I, p. 497-506; S. Van Garsse, 'De 'harmonicabewegingen' van het begrip administratieve overheid', T. Gem., 2002, p. 308-313.

26. Arbitragehof nr. 89/2004, I9 mei 2004 .

27. Laatste wijziging aan artikel I4, § I, $2^{\circ}$ R.v.St.-wet werd aangebracht door de wet van $5_{5}$ mei 2007 tot wijziging van artikel I4 van de wetten op de Raad van State, gecoördineerd op I2 januari I973 (B.S. 8 juni 2007). 
Hoge Raad voor de Justitie met betrekking tot overheidsopdrachten en leden van hun personeel, door de Raad van State kunnen worden vernietigd. ${ }^{28}$

Op het vlak van de aanvechtbare administratieve rechtshandeling is het zo dat (ook) afsplitsbare rechthandelingen (vb. eenzijdige rechtshandelingen die een overeenkomst voorafgaan of daarop volgen) evenals zgn. vóórbeslissingen kunnen worden aangevochten. ${ }^{29}$ Het is evenwel niet altijd eenvoudig om uit te maken of een handeling aanvechtbaar is of niet. ${ }^{30}$

De R.v.St.- wet voorziet voorts dat impliciet afwijzende beslissingen voor vernietiging vatbaar zijn. ${ }^{3 \mathrm{I}}$

Ten slotte kunnen enkel definitieve, in laatste aanleg genomen beslissingen voor de Raad van State worden aangevochten. Bijgevolg moeten de voorafgaande door de vigerende wetgeving georganiseerde beroepen uitgeput zijn. ${ }^{32}$

\subsubsection{De vernietigingsgronden of vernietigingsmiddelen}

De R.v.St.-wet voorziet drie vernietigingsgronden 33 ter staving van een vernietigingsberoep, met name, machtsoverschrijding, machtsafwending en de niet-naleving van substantiële of op straffe van nietigheid voorgeschreven vormen. In de rechtsleer wordt deze opsomming echter bekritiseerd. Het gebruik van het generieke begrip 'machtsoverschrijding' naast de opsomming van twee specifieke gevallen van machtsoverschrijding, met name de schending van de vormen en de machtsafwending zou aanleiding geven tot verwarring. Bepaalde rechtsleer hanteert traditioneel een ander onderscheid, met name, de vernietigingsgronden betreffende de externe wettigheid en de vernietigingsgronden betreffende de interne wettigheid. 34

Onder de eerste categorie van onwettigheden worden verstaan, de bevoegdheid ofte onwettigheden met betrekking tot de steller van de administratieve rechtshandeling en de naleving van substantiële of op straffe van nietigheid voorgeschreven vormen. 35

Onder de tweede categorie van onwettigheden worden verstaan de onwettigheden betreffende de inhoud van de bestreden rechtshandeling en deze met betrekking tot het door de handeling nagestreefde oogmerk (machtsafwending). ${ }^{36}$

Wat de interne wettigheid van de bestreden administratieve rechtshandeling betreft, is het uitsluitend de algemene vergadering van de afdeling Bestuursrechtspraak van de Raad van State die bevoegd is om kennis te nemen van het middel van

28. A. Mast, J. Dujardin, M. Van Damme, J. Vande Lanotte, o.c., p. 973-979.

29. A. Mast, J. Dujardin, M. Van Damme, J. Vande Lanotte, o.c., p. 982.

30. J. Baert, G. Debersaques, Raad van State Afdeling Administratie. Ontvankelijkheid, Brugge, Die Keure, I996, p. 8.

3I. Artikel I4, § 3 R.v.St.-wet.

32. A. Mast, J. Dujardin, M. Van Damme, J. Vande Lanotte, o.c., p. 983.

33. A. Wirtgen, l.c., p. 9. Deze auteur spreekt van 'middelen' omdat volgens haar de begrippen 'middel' en 'vernietigingsgrond' eenzelfde lading dekken. Deze auteur geeft zelf de voorkeur aan het begrip 'middel' omdat deze terminologie terugkomt in het Procedurereglement.

34. A. Mast, J. Dujardin, M. Van Damme, J. Vande Lanotte, o.c., p. 928-929.

35. A. Mast, J. Dujardin, M. Van Damme, J. Vande Lanotte, o.c., p. 930 e.v.

36. A. Mast, J. Dujardin, M. Van Damme, J. Vande Lanotte, o.c., p. 936 e.v. 
de machtsafwending. De Raad heeft evenwel maar een zeer beperkt aantal vernietigingen op deze grond uitgesproken. ${ }^{37}$

\subsubsection{De rol van de partijen}

De rol van de partijen bij het verloop van de procedure tot nietigverklaring voor de Raad van State is belangrijk, doch valt evenwel te nuanceren. Zoals hierboven reeds kort werd uiteengezet, is de procedure inquisitoriaal en ligt de leiding ervan in handen van de Raad van State.

Dit kan worden verklaard door de ongelijke positie tussen de burger en het bestuur in hun onderlinge verhoudingen hetgeen, enerzijds uit de overheersende positie van de overheid, en anderzijds, de moeilijkheid van de bestuurde om een fout in hoofde van de overheid aan te tonen, voortvloeit. Bijgevolg hindert deze verhouding de gelijkheid tussen de partijen, zoals deze gewoonlijk is gewaarborgd voor de gewone hoven en rechtbanken. Daarom is de leiding aan de Raad van State opgedragen, en niet aan de partijen.

Evenzeer zal in tegenstelling tot het burgerlijk procesrecht, de bewijslast niet beantwoorden aan de adagia actor incumbit probation en reus in excipiendo fit actor. De verzoekende partij moet niet de onwettigheid van de bestreden rechtshandeling bewijzen, maar moet enkel uiteenzetten waarin de vermeende onwettigheid bestaat en het is vervolgens aan de administratieve overheid om de wettigheid ervan aan te tonen. De Raad van State heeft uitgebreide onderzoeksbevoegdheden en kan zich door een terughoudende administratieve overheid alle dienstige bescheiden en inlichtingen laten overleggen.

De rechtspleging wordt geleid door de Raad van State en de procedure is, zoals hoger reeds gezegd, in essentie schriftelijk van aard. De partijen zijn er hoofdzakelijk toe gehouden om in het inleidend verzoekschrift en de memories al hun middelen uiteen te zetten hetgeen veronderstelt dat de beweerde grieven, nadelen en middelen worden ontwikkeld. Zo kan uiteraard niet worden volstaan met een nietszeggend verzoekschrift. Aldus oordeelde de Raad van State nog recentelijk dat in een schorsingsprocedure die gekenmerkt wordt door een meer feitelijke benadering, zelfs bij uiterst dringende noodzakelijkheid, het beweerde moeilijk te herstellen ernstig nadeel (minstens) aannemelijk moet worden gemaakt en niet kan worden volstaan met gratuite beweringen die niet worden geconcretiseerd noch door enig stuk aannemelijk worden gemaakt. Zo volstaat, bij wijze van voorbeeld, de loutere bewering niet dat 'het duidelijk is dat aangezien de betoging gepland is voor II september 2007 , een symbolische datum, ... de voorbereidingen hiervan verder moeten kunnen worden gezet en de tenuitvoerlegging van de beslissing nl. het verbod (door de burgemeester van de Stad Brussel) van de manifestatie een bijzonder ernstig nadeel berokkent aan verzoeker en aan de idee die hij voorstaat en vooral aan de organisatie en de duizenden mensen die zich klaarmaken om aan de betoging deel te nemen'.${ }^{38}$ Dergelijke beweringen moeten immers, op aannemelijke wijze, worden geconcretiseerd.

37. A. Mast, J. Dujardin, M. Van Damme, J. Vande Lanotte, o.c., p. 94I.

38. R.v.St., Ulfkotte, nr. I74.732, 29 augustus 2007. 
Omgekeerd, mag van een verzoekschrift ook worden verwacht dat het beantwoordt aan de gekozen rechtsingang. De Raad van State lijkt slechts matig te appreciëren wanneer in een schorsingsprocedure, laat staan in een spoedprocedure, talrijke middelen worden aangewend en uitvoerig uitgesponnen, dikwijls opgesplitst in meerdere onderdelen om te bewijzen dat sprake is van een ernstig middel. Bovendien zou daaruit ook een ongefundeerde verwachting van de rechtszoekenden kunnen blijken dat in een dergelijke uiterst dringende spoedprocedure in wezen op dezelfde wijze als in een annulatieprocedure de grond van de zaak uitputtend kan worden behandeld en beslecht. 39

De partijen dienen voorts hun medewerking te verlenen aan het verloop van de rechtspleging. ${ }^{40}$ Zo kunnen ze de procedure niet dwarsbomen door stil te zitten..$^{4 \mathrm{I}}$ Er zijn in de procedure namelijk een aantal vermoedens van verlies aan belang of van afstand van geding ingebouwd in hoofde van de partij - zowel verzoekende, als, thans, verwerende partij - die in gebreke blijft om een procedurestuk over te maken en meer in het bijzonder, die verzuimt om een verzoek tot voortzetting van de procedure in te dienen. ${ }^{42}$

Een procespartij die zich tot de Raad van State wendt, moet zich te allen tijde loyaal gedragen, dus zowel bij het inleiden van de zaak, de behandeling ervan, als bij de uitvoering van het arrest. Deze vereiste is mede ingegeven door de zorg om het recht van verdediging en de goede werking van de rechtsinstantie te waarborgen. Bijgevolg worden in de R.v.St.-wet een aantal procédés tegen dilatoir procesgedrag aangereikt. ${ }^{43} \mathrm{Bij}$ wijze van voorbeeld kan worden gewezen op de geldelijke sancties wanneer de Raad van State op roekeloze wijze wordt gevat of de recent ingevoerde procedurefilter bij het instellen van een cassatieberoep.

E. Brewaeys wijst erop dat richtinggevend bij de beoordeling van de toelaatbaarheid van het procesgedrag in het respect voor het tegensprekelijk karakter van het debat en de uitoefening van het recht van verdediging van de andere partijen. Meer en meer rijst echter de vraag of ook de overbevraging en de overbelasting van rechtsinstantie en de daaruit voortvloeiende achterstand, in aanmerking kan of moet worden genomen om dergelijk deloyaal gedrag te beoordelen. ${ }^{44}$ In dat verband moet

39. R.v.St., NV Antwerpse bouwwerken, nr. I65.404, 30 november 2006.

40. P. Gerard, 'Les spécificités de la procédure administrative', in X, Le Conseil dEtat de Belgique. Cinquante ans après sa création (1946-1996), Brussel, Bruylant, I999, p. 4I5.

4I. M. Leroy, o.c., p. 473 .

42. Na een eerste uitwisseling van memories is een auditeur, lid van het auditoraat van de Raad van State, ertoe gehouden in een verslag de ingeroepen middelen te onderzoeken. In het verslag moet de auditeur tevens een voorstel formuleren aangaande de verwerping van de zaak of de vernietiging van de bestreden beslissing. In het eerste geval zal de verzoekende partij een verzoek tot voortzetting van de rechtspleging moeten indienen. Bij ontstentenis van dergelijk verzoek zal de afstand van geding worden uitgesproken. In het tweede geval zal, sinds I juni 2007, de verwerende partij een verzoek tot voortzetting van de rechtspleging moeten indienen, bij ontstentenis waarvan de nietigverklaring zal worden uitgesproken na een verkorte procedure. Binnen het bestek van deze bijdrage zal evenwel niet in detail worden ingegaan op de procedurele aspecten.

43. Zie G. Debersaques, M. Van Damme, e.a. (ed), o.c., p. 67.

44. Zie E. Brewaeys, 'Deloyaal procesgedrag in de procedure voor de Raad van State', in G. Debersaques, M. Van Damme, S. De Clercq en G. Laenen (eds.), Administratieve rechtsbibliotheek. 4. Rechtsbescherming door de Raad van State. 15 jaar procedurele vernieuwing, Brugge, die Keure, 2004, p. 67. 
onder meer de mogelijkheid worden gesitueerd om, na daartoe een hoorzitting te hebben bevolen, een geldboete op te leggen wegens het 'kennelijk onrechtmatig beroep' bij de Raad van State (art. 37 R.v.St.-wet).

\subsubsection{De rol van de Raad van State}

1 Het voorwerp van het vernietigingsberoep

Een beroep tot nietigverklaring heeft een bestuurshandeling tot voorwerp. Het voorwerp van deze handeling kan formeel en materieel worden bepaald. Formeel betreft het datgene wat is de bestreden bestuurshandeling te lezen staat. Zo heeft een benoemingsbesluit de vaste benoeming van een welbepaalde ambtenaar in een welbepaald ambt tot formeel voorwerp. Het materiële voorwerp kan ruimer zijn en betreft de eigenlijke inhoud ervan. Het gaat dan 'om de hele reeks rechtseffecten die men door middel van het formeel uitgedrukt voorwerp wil bereiken en die bestaan ... in het vestigen of bevestigen van rechtsverhoudingen waarin aan één of meer actieve rechtssubjecten bevoegdheden of rechten worden toegewezen en, uiteraard tegelijkertijd, correlatieve verplichtingen aan de corresponderende passieve rechtssubjecten worden opgelegd'. 45 Zo behoort, bij wijze van voorbeeld, ook de impliciete nietbenoeming van een andere ambtenaar tot het materiële voorwerp van het benoemingsbesluit, of, nog, de vaststelling van de plaats van de benoemde in de ambtelijke hiërarchie, zijn plaatsinneming qua anciënniteit in het betrokken ambt, en dergelijke meer. Naast voormelde directe rechtsgevolgen welke voortvloeien uit de bestuurshandeling, zijn er ook indirecte rechtsgevolgen. Het betreft rechtshandelingen die niet kunnen worden teruggebracht tot de initiële handeling zelf maar die later op grond van die initiële handeling zijn genomen. Zo bijvoorbeeld de onteigeningbeslissing die wordt genomen nadat het orgaan daartoe werd gemachtigd op grond van een machtigingsbesluit.

In dat kader is op te merken dat de Raad van State het voorwerp van het beroep zoals het formeel is uitgedrukt (ambtshalve) uitbreiden kan en rechtshandelingen of rechtsgevolgen bij de vernietiging betrekken kan waarvan de vernietiging niet formeel werd gevraagd. ${ }^{46}$ Soms doet hij dat door interpretatie van het verzoekschrift; in andere gevallen gaat hij een stap verder en betrekt hij bestuurshandelingen in zijn arrest die de verzoeker nochtans niet bedoeld heeft aan te vechten. Zo kan het beroep worden uitgebreid tot een aan de bestreden beslissing voorafgaande bevestigde beslissing op voorwaarde dat het beroep werd ingediend binnen de termijn die openstaat voor een beroep tegen de bevestigde beslissing. Ook het voorwerp van het beroep tegen een goedkeuringsbeslissing werd uitgebreid tot de goedgekeurde beslissing of wordt overgegaan tot de vernietiging van rechtshandelingen die deel uitmaken van een zgn. complexe verrichting die tot de bestreden eindbeslissing heeft geleid maar zelf niet formeel werden, aangevochten, etc.

De vraag rijst naar de verenigbaarheid van de ambtshalve uitbreiding van het voorwerp van een vernietigingsberoep met het beginsel ne est judex ultra petita partium. De

45. R.v.St., Tibax, nr. 20.599, 30 september 1980.

46. S. Lust, 'Raad van State. Afdeling Administratie. 6. Rechtsherstel door de Raad van State', in X, Administratieve rechtsbibliotheek, Brugge, Die Keure, 2000, p. 259. 
inquisitoire aard van de rechtspleging, is geen (voldoende) grond is om tot dergelijk 'ambtshalve uitbreiding' over te gaan. Toch wordt veelal aangenomen dat er geen probleem hoeft te rijzen zolang de Raad van State tot een uitbreiding komt door een naar redelijkheid aanvaardbare (?) extensieve interpretatie van het materiële voorwerp van het verzoekschrift.

\section{Kennisneming van de feiten}

Zoals hierboven reeds is uiteengezet, is de Raad van State belast met de wettigheidscq. rechtmatigheidscontrole van administratieve rechtshandelingen wat inhoudt dat hij kennis neemt van de inhoud van deze rechtshandelingen en ertoe gehouden is na te gaan of er geen machtsoverschrijding is.

Teneinde na te gaan of er machtsoverschrijding is, zal de Raad van State, ingevolge een jarenlange evolutie in zijn rechtspraak, de aan de administratieve rechtshandeling ten grondslag liggende motieven controleren. ${ }^{47}$ De controle op de motieven is het middel bij uitstek om de wettigheid van de bestuurshandeling te toetsen.

Oorspronkelijk beperkte de Raad van State zijn controle tot de rechtshandelingen die formeel moesten worden gemotiveerd en beperkte zich tot die gevallen waar de auteur van de rechtshandeling geen soevereine appreciatiebevoegdheid had ten aanzien van de feiten. ${ }^{4}$

De controle is doorheen de jaren substantieel geëvolueerd in die zin dat de Raad van State zich nog steeds zal onthouden om zijn motieven in de plaats te stellen van die van de administratieve overheid, maar dat hij niettemin van dichtbij zal onderzoeken hoe de administratieve overheid gebruik makt van haar discretionaire beoordelingsbevoegdheid. 49

Bijgevolg zal overeenkomstig vaste rechtspraak, elke administratieve rechtshandeling, ongeacht of deze onderworpen is aan een formele motiveringsverplichting, moeten rusten op motieven in rechte en in feite die duidelijk, pertinent en deugdelijk zijn en die desnoods moeten blijken uit het administratief dossier dat tijdens de totstandkomingsprocedure van de rechtshandeling is opgebouwd..$^{\circ}$

Tegen deze achtergrond is de Raad van State ertoe gehouden om kennis te nemen van de feiten die hem worden voorgelegd. Vooreerst moet het verzoekschrift luidens artikel 2 van het Procedurereglement immers de feiten en middelen bevatten. Ook de arresten beginnen met een feitenrelaas warna dan, met betrekking tot de aangevoerde middelen, de toepassing van de rechtsregel wordt verklaard. Uit de jurisprudentie van de Raad van State blijkt dat de Raad van State om zijn wettigheidscontrole te kunnen uitoefenen, enerzijds, moet nagaan of de motieven op grond waarvan de bestuurshandelingen werden genomen, in feite toelaatbaar zijn en, anderzijds, of de feiten juist werden gekwalificeerd.

47. Zie M. Leroy, o.c., p. 392 e.v.; P. Lewalle, Contentieux administratif, Brussel, Larcier, 2002, nr. 505 e.v., p. 892 e.v.

48. M. Leroy, o.c., p. 392.

49. Ibidem.

50. M. Leroy, o.c., p. 393. 
De overheid waarvan een rechtshandeling wordt betwist, zal bijgevolg niet kunnen volstaan met het inroepen van een feitelijk gegeven dat voorkomt in de aanhef van de rechtshandeling ten einde deze te rechtvaardigen; immers, het feit moet zijn vastgesteld en, desgevallend, zal de juistheid ervan door de Raad van State worden onderzocht. Het voorgaande betekent niet dat de Raad van State - wanneer hij optreedt in het kader van een vernietigingsberoep - optreedt als een rechter in hoger beroep die op verzoek van de rechtszoekende de ware toedracht van de feiten gaat vaststellen. Hij onderzoekt daarentegen wel of de overheid in redelijkheid is kunnen komen tot de door haar gedane vaststelling van feiten en of in het dossier geen gegevens voorhanden zijn die daarmee onverenigbaar zouden zijn. Voorts onderzoekt de Raad van State of de beslissing niet onregelmatig is omwille van een foutieve kwalificatie van het feitelijke gegevens. ${ }^{{ }^{\mathrm{I}}} \mathrm{Hij}$ zal derhalve onderzoeken of de feiten die de overheid ertoe hebben aangezet een administratieve rechtshandeling te stellen rechtens juist werden gekwalificeerd. Bondig gesteld: de Raad van State beperkt er zich niet toe te kijken naar wat het bestuur (of de rechtsonderhorige) zegt te doen maar naar wat het in de feiten doet.

Gemis aan, foutieve of gebrekkige verantwoording van een bestuurshandeling wat de feitelijke gegevens betreft, zal in ieder geval moeten resulteren in nietigheid omwille van onbestaande of onjuiste, niet draagkrachtige motieven.

\section{Substitutie van (overheids)motieven}

De Raad van State zal in bepaalde gevallen een geldig motief in de plaats kunnen stellen van het door hem ondeugdelijk geachte motief waarop de voor hem bestreden beslissing berust. Hij verricht in zulk geval een substitutie van motieven. Een dergelijke substitutie van motieven zal uiteraard niet onbeperkt kunnen worden doorgevoerd. Men dient immers voor ogen te houden dat de administratieve overheid waaraan de wet de bevoegdheid heeft gegeven om een beslissing te nemen, in beginsel zelf en alleen moet kunnen oordelen over de redenen die haar ertoe hebben aangezet van die bevoegdheid gebruik te maken. Daartegenover staat dat een goede rechtsbedeling eist dat, in de mate van het mogelijke, onmiddellijk aan het geschil een einde wordt gemaakt. De algemene strekking van de rechtspraak van de Raad van State kan als volgt worden samengevat: substitutie van motieven is pas mogelijk wanneer de overheid, waarvan de beslissing wordt bestreden, over een gebonden bevoegdheid beschikt: de Raad van State kan geen motief in de plaats stellen van dat van het optredend bestuur indien dat motief afhankelijk is van appreciatie. ${ }^{22}$

De inhoud van de beslissing, namelijk wat werd beslist, moet onaangeroerd blijven. Indien een kandidatuur wordt afgewezen omdat de gegadigde de leeftijdsgrens voorbij is doch dit motief onjuist is omdat de toepasselijke regelgeving toelaat dat de kandidaat op grond van zijn leeftijd nog in aanmerking kwam maar de Raad van State evenzeer moet vaststellen dat de betrokkene toch niet kan worden benoemd omdat hij niet over het vereiste diploma beschikt, vermag de Raad van State het motief substitueren. 53

51. M. Leroy, o.c., p. 396.

52. A. Mast, J. Dujardin, M. Van Damme, J. Vande Lanotte, o.c., p. 760-76r.

53. D. Mareen, 'Het motiveringsbeginsel', in I. OPDEBEEK en M. VAN DAMME (eds.), Administratieve rechtsbibliotheek, Algemene beginselen van behoorlijk bestuur, l.c., 2006, p. I6o. 
Substitutie van motieven zal meer voorkomen wanneer de Raad van State optreedt als cassatierechter. ${ }^{54}$

4 De aanuulling van de aangevoerde middelen

De verzoekende partij is ertoe gehouden om in zijn inleidend verzoekschrift alle middelen uiteen te zetten waarmee hij de nietigverklaring van de bestreden rechtshandeling wenst te bekomen, op straffe van miskenning van de rechten van verdediging. 55

Het middel dat niet van openbare orde is en waarvan verzoeker reeds kennis kon hebben ten tijde van het indienen van het verzoekschrift kan later niet worden ingeroepen in de memorie van wederantwoord, in de laatste memorie of ter zitting. ${ }^{56}$

Het wettigheidsonderzoek wordt evenwel uitgebreid naar de middelen die de verzoeker pas na het verstrijken van de beroepstermijn inroept, wanneer het middelen betreft die hij niet eerder had kunnen inroepen. Hierbij kan worden gedacht aan middelen die verzoekende partij pas kan inroepen na kennis te hebben genomen van het volledige administratieve dossier van verwerende partij. Ook de middelen van openbare orde, die de verzoekende partij pas na het verstrijken van de beroepstermijn aanvoert, worden door de Raad van State nog ontvankelijk verklaard (zie nog infra). ${ }^{57}$

Teneinde ontvankelijk te zijn, moet het verzoekschrift minstens één middel bevatten.

Het middel moet aanduiden welke rechtsregel werd geschonden en omschrijven hoe die rechtsregel werd overschreden, evenwel zonder dat het vereist is dat in het verzoekschrift uitdrukkelijk de vindplaats van de wettelijke of reglementaire bepaling moet zijn vermeld: het voornaamste is dat er geen redelijke twijfel kan bestaan omtrent de regel of het beginsel waarvan de schending wordt aangevoerd. ${ }^{58}$

Voor een toetsing van de inhoud van de bestreden rechtshandeling, wordt gekeken naar strijdigheden met de wet in zijn meest algemene materiële betekenis: 'Cette règle de droit, peut aussi être non écrite, ou se dégager de la jurisprudence'. ${ }^{9}$ Bijgevolg dient de bestreden rechtshandeling ook conform te zijn aan het verdragsrecht en meer bepaald aan het communautair recht en het Europees Verdrag tot bescherming van de Rechten van de Mens, evenals aan de algemene beginselen van behoorlijk bestuur. ${ }^{60}$ Wat dat laatste betreft, is het genoegzaam bekend welke rol de Raad van State heeft vervuld bij het ontwikkelen van het leerstuk van de algemene beginselen van behoorlijk bestuur en de curatieve en preventieve rechtsbeschermende factor daarvan hoewel het geen uitdrukkelijk in de R.v.St.-wet opgenomen vernietigingsgrond betrof doch probleemloos kon worden ondergebracht onder het begrip 'machtsoverschrijding' in artikel I4, SI R.v.St.-wet. ${ }^{6 \text { I }}$

54. Ibidem en de aldaar geciteerde rechtspraak.

55. A. Mast, J. Dujardin, M. Van Damme, J. Vande Lanotte, o.c., p. II5 (voetnoot I7).

56. A. Mast, J. Dujardin, M. Van Damme, J. Vande Lanotte, o.c., p. III6.

57. A. Wirtgen, l.c., p. 62.

58. M. Leroy, o.c., p. 538 e.v.

59. A. Arts, I. Verougstraete e.a. (eds.), o.c., p. I6 e.v.

6o. A. Arts, I. Verougstraete e.a. (eds.), o.c., p. I8.

6r. I. Opdebeek en M. Van Damme, 'Beginselen van behoorlijk bestuur', in I. Opdebeek en M. Van Damme (eds.), Administratieve rechtsbibliotheek, I., Brugge, Die Keure, 2006, p. 49I. 
Voorts stelt de Raad van State zich weinig formalistisch op met betrekking tot de wijze waarop de rechtsregel moet worden geformuleerd. De administratieve rechter kan en moet het verzoekschrift interpreteren. Hij zal daarbij meer belang moeten hechten aan wat de verzoeker in werkelijkheid vraagt, dan aan de bewoording waarin het beroep is gesteld. ${ }^{62}$

De interpretatie van de middelen van het verzoekschrift is niettemin een delicate zaak. Enerzijds, mag de Raad van State de argumenten van de verzoeker niet 'aanvullen' op zodanige wijze dat middelen zouden worden behandeld, die in werkelijkheid niet werden ingeroepen door de verzoeker en die ook niet de openbare orde aanbelangen (zie infra). Anderzijds, mag de Raad van State de middelen van het verzoekschrift niet te strikt interpreteren, omdat zulks niet zou stroken met het minder formalistische karakter dat de wetgever heeft willen geven. In dit verband kan opgemerkt worden dat de Raad van State bij de interpretatie van het verzoekschrift getuigt van begrip en welwillendheid, zeker wanneer het verzoekschrift werd opgesteld door de verzoeker zonder de hulp van een advocaat. ${ }^{63}$

Toch zijn er grenzen aan de soepele, weinig formalistische houding van de Raad van State om te voorkomen dat de Raad van State zich in werkelijkheid aan de verzoeker substitueert en het uiteindelijk de rechter wordt die de overheid een proces aandoet, in de plaats van de geadministreerde. Een dergelijke handelwijze van de Raad van State zou immers onverenigbaar zijn met het algemeen geldend beginsel, dat een rechter maar tot het uitoefenen van de hem toegekende bevoegdheden gemachtigd is, indien hij daartoe regelmatig door een rechtzoekende of bevoegde overheid gevorderd wordt. 64

5 De middelen van openbare orde en het ambtshalve aanvoeren van middelen

Hoewel de Raad van State in beginsel zijn wettigheidsonderzoek uitoefent op de door de verzoeker op ontvankelijke wijze ingeroepen middelen, kan de Raad van State ook ambtshalve een aantal middelen aanvoeren. De Raad van State zal dan tot een uitspraak komen aan de hand van rechtsmiddelen die hijzelf, en niet de partijen, heeft opgeworpen. ${ }^{6}$ In voorkomend geval gaat de Raad van State over tot een zogeheten ambtshalve wettigheidsonderzoek en zullen de ambtshalve opgeworpen middelen meestal de verdere afloop van het vernietigingsberoep determineren. ${ }^{66}$

De Raad van State heeft van meet af aan een restrictieve opvatting gehuldigd wat betreft zijn mogelijkheid om middelen ambtshalve op te werpen en is steeds van oordeel geweest dat alleen de middelen van openbare orde zich daartoe lenen. ${ }^{67}$ In zijn rechtspraak zal de Raad van State dat begrip overigens niet altijd met zoveel woorden hanteren. ${ }^{68} \mathrm{Er}$ is gesteld dat de opvatting van de Raad van State over het al

62. A. Wirtgen, l.c., nr. 31, p. 32.

63. A. Wirtgen, l.c., nr. 32, p. 32; P. Gerard, 'Les spécificités de la procédure administrative', in X (ed.), Le Conseil d'Etat de Belgique. Cinquante ans après sa création (1946-1996), Brussel, Bruylant, I999, p. 409 .

64. A. Wirtgen, l.c., nr. 33, p. 34 .

65. A. Mast, J. Dujardin, M. Van Damme, J. Vande Lanotte, o.c., p. 758 e.v.; A. Wirtgen, l.c., p. 3 e.v.

66. A. Wirtgen., l.c., p. 3.

67. A. Wirtgen, l.c., p. 466-47I.

68. A. Mast, J. Dujardin, M. Van Damme, J. Vande Lanotte, o.c., p. 759. 
dan niet tot de openbare orde behoren van bepaalde middelen is gewijzigd, wat echter evident lijkt, gegeven het evolutief karakter van het begrip 'openbare orde.

Overeenkomstig vaste jurisprudentie van de Raad van State worden onder meer van ambtswege opgeworpen, de middelen die betrekking hebben op de onbevoegdheid van de steller van de bestreden handeling, de niet- of gebrekkige raadpleging van de afdeling wetgeving van de Raad van State, het gebrek aan rechtsgrond, het middel gesteund op de schending van het gezag van gewijsde van een vroeger vernietigingsarrest, het middel gesteund op de schending van een bepaling van het E.V.R.M.

Het hoofdkenmerk van het middel van openbare orde binnen de rechtspleging van de Raad van State is, aldus A. wirtgen, dat het betrekking heeft op wat binnen het algemeen belang als fundamenteel wordt beschouwd vanuit administratiefrechtelijke invalshoek. Het middel van openbare orde werpt de schending op van rechtsregels of rechtsbeginselen die aan de gehele rechtsordening ten grondslag liggen en waarvan de naleving een basisvoorwaarde vormt voor de rechtsstaat.

Nergens schrijven de gecoördineerde wetten op de Raad van State of het Procedurereglement voor dat de Raad van State vernietigingsmiddelen ambtshalve kan of moet opwerpen. ${ }^{69}$ Evenwel heeft de Raad van State zichzelf deze bevoegdheid gegeven. Het opwerpen van middelen van openbare orde heeft een aantal juridische gevolgen waaronder het feit dat wordt afgeweken van de regel dat het middel moet worden ingeroepen binnen de vervaltermijn om beroep in te stellen, dat de voorwaarde dat het middel op voldoende duidelijke wijze moet gesteld zijn, niet geldt, of nog dat de verzoeker in beginsel niet moet getuigen van een belang. ${ }^{70}$

Of de terughoudendheid ten aanzien van het ambtshalve opwerpen van middelen is geëvolueerd, is minder duidelijk. Uit het door A. Wirtgen uitgevoerde onderzoek bleek bijvoorbeeld dat de vraag of de Raad van State in het kader van een schorsingsprocedure ambtshalve ernstige middelen van openbare orde mocht opwerpen niet eenduidig werd beantwoord. Zij refereert immers aan arresten waarin de Raad van State zich dat recht heeft ontzegd; terwijl andere arresten tot schorsing besloten op grond van een ambtshalve opgeworpen ernstig middel. Nog andere formuleerden een tussenoplossing, te weten dat het de Raad van State in principe niet toekomt binnen het raam van een schorsingsprocedure, middelen van openbare orde die bij het onderzoek van het dossier aan het licht komen ambtshalve op te werpen en dat - als bij wijze van uitzondering zulks toch kan gebeuren - dit is op voorwaarde dat de begane onwettigheid derwijze duidelijk is dat zij geen langdurig en nauwgezet onderzoek vereist en dat alle aspecten ervan ter terechtzitting mondeling kunnen worden besproken.

Interessant is ook de discussie rond het al dan niet begrijpelijke karakter van de houding om de schending van het gelijkheidsbeginsel op te vatten als een 'gewoon' middel. Volgens de enen zou het gelijkheidsbeginsel enkel de bescherming van de burger dienen en zou de aantasting ervan enkel die individuele burger schaden doch

69. A. Wirtgen, l.c., p. 469 .

70. In sommige rechtspraak eist de Raad van State evenwel een belang. A. Wirtgen, l.c., p. 483 . 
niet de maatschappelijke ordening als zodanig; hetgeen door anderen stellig wordt betwist.

6 Marginale toetsing in geval de administratieve overheid een discretionaire bevoegdheid heeft

Zoals hierboven reeds werd uiteengezet, zal de Raad van State - hoewel hij zich niet inlaat met de opportuniteit van de rechtshandeling en dus niet in de plaats van het bestuur zal optreden -, nagaan hoe de administratieve overheid haar discretionaire beoordelingsbeslissing aanwendt.

De discretionaire beoordelingsbeslissing van de administratieve overheid wordt getoetst door de Raad van State en mag in geen geval synoniem zijn van een arbitraire beoordelingsvrijheid. Evenwel, zo wordt gesteld, zal de Raad van State enkel nagaan of er geen kennelijk misbruik is van de beoordelingsvrijheid. Met andere woorden is het de taak van de Raad van State om na te gaan of het gedrag van de administratieve overheid niet kennelijk onredelijk is. ${ }^{7 \mathrm{I}}$ De rechter eerbiedigt met andere woorden de beleidsvrijheid van het bestuur maar sanctioneert de bestuursbeoordeling waartoe geen redelijk denkend persoon bij een afweging van de betrokken belangen had kunnen geraken. De voorwaarden van een wettige uitoefening van de beleidsvrijheid zijn dan immers niet vervuld.

Over de vraag hoe (kennelijk) onredelijk de bestuurshandeling moet zijn opdat de Raad van State zou vernietigen of, omgekeerd, hoe terughoudendend of marginaal, de beoordeling moet zijn waar het bestuur over beleidsvrijheid beschikt, is al genoeg inkt gevloeid.

\subsubsection{Keuze van het vernietigingsmotief}

De Raad van State beschikt in beginsel over een discretionaire beoordelingsbevoegdheid om het vernietigingsmotief te kiezen. De Raad van State kan hiertoe één middel, maar evengoed meerdere of zelfs allemaal in aanmerking nemen.

In het verleden hanteerde de Raad van State vaak het criterium van de 'ruimste vernietiging' wat inhoudt dat het een middel niet zal onderzoeken wanneer het niet tot een ruimere vernietiging kan leiden dan een vernietiging uitgesproken op grond van een ander middel. De toepassing in de rechtspraak van dit criterium kwam echter onder druk te staan door ingrepen van de wetgever die van oordeel was dat het zoeken naar het verst reikend middel 'vaak regelrecht ingaat tegen het belang van de verzoekende partij'. ${ }^{72}$

De wet voorziet dat de Raad van State bij het stilzwijgen van de verzoekende partij, zijn onderzoek moet beperken tot datgene wat de auditeur in zijn verslag gegrond bevond. Dat hij, wanneer hij de conclusie van de auditeur over het middel bijvalt, de vernietiging op die grond dient uit te spreken, ook al is het middel zijns inziens niet het 'verst reikend'. Elk van de partijen kan zich nochtans uitspreken over de keuze van de auditeur. De verzoekende partij kan bijgevolg verzoeken dat de vernietiging

7I. M. Leroy, l.c., p. 400.

72. A. Wirtgen, l.c., p. 385 . 
wordt bekomen op grond van een ander middel. In de praktijk blijkt dit evenwel zelden voor te komen. De Raad van State zelf heeft, gelet op de inquisitoriale aard van de procedure, de uiteindelijke beslissingsbevoegdheid en kan eventueel aanvullend onderzoek bevelen. Uit rechtspraak blijkt dat de Raad van State in bepaalde gevallen blijft zoeken naar het ruimste middel. ${ }^{73}$

\subsubsection{Draagwijdte van de arresten}

1 Het vernietigingsarrest

Aan de Raad van State werd de bevoegdheid gegeven om bij wijze van rechtsherstel onwettige bestuurshandelingen de vernietigen; dat wil zeggen hen voor het verleden en de toekomst uit de rechtsordening verwijderen zodat zij geacht worden nooit te hebben bestaan. Het vernietigingsarrest heeft niet alleen tot gevolg dat de vernietigde rechtshandeling niet meer bestaat, maar bovendien dat ze geacht wordt nooit te hebben bestaan en dit ten aanzien van eenieder. ${ }^{74}$ Olmwille van de aard van de vernietiging zelf, geldt ze erga omnes. Bijgevolg, is het arrest zowel tegenstelbaar aan de administratieve overheid die de beslissing heeft gewezen, als aan derden. ${ }^{75}$ Het erga omnes karakter mag dan ook niet worden miskend door de burgerlijke rechter, ${ }^{76}$ voor wie de rechtshandeling eveneens geacht wordt nooit te hebben bestaan.

Voorts blijft het gezag van gewijsde (erga omnes) van een vernietigingsarrest niet beperkt tot het dispositief van het arrest en dus tot de vernietiging maar strekt het zich uit tot de motieven die hieraan ten grondslag liggen en er de noodzakelijke ondersteuning van uitmaken. Deze determinerende motieven geven de vernietigingsgrond aan, d.w.z. 'de vaststelling, afgeleid uit de feitelijke en juridische gegevens die zich voordeden op het ogenblik dat de bestreden beslissing genomen werd, van de toen op de bestuursoverheid rustende concrete rechtsplicht waaraan die overheid bij het verrichten van de vernietigde bestuurshandeling tekortgekomen is. De vernietigingsgrond geeft aldus de onontbeerlijke juridische rechtvaardiging voor het besluit van de rechter om te verneitigen en is daarom onverbrekelijk met het dictum van de uitspraak verbonden'. ${ }^{77}$ Het voorgaande brengt mee dat iedereen zal moeten aanvaarden dat de overheid, in voorkomend geval, na de verneitiging nog bepaalde maatregelen zal kunnen en zelfs moeten nemen en iedereen daarvan de effecten zal moeten ondergaan. Soms worden die maatregelen zelfs in de motivering van het arrest vermeld $;^{78}$ al zullen ze er doorgaans door de ovrerheid uit moeten worden afgeleid.

Hoever de Raad van State in het aangeven van het te verlenen rechtsherstel kan gaan of zelfs moet gaan, kan een punt van discussie zijn.

Hoe dan ook, is de uitwerking van het erga omnes karakter dan ook weer niet onbeperkt aangezien traditioneel wordt aanvaard dat enkel de verzoekende en de eventu-

73. A. Wirtgen, l.c., p. 384 e.v. en de daar aangehaalde referenties.

74. M. Leroy, o.c., p. 706.

75. A. Mast, J. Dujardin, M. Van Damme, J. Vande Lanotte, o.c., nr. 997, p. 97I.

76. P. Lewalle, o.c., nr. 5io e.v.

77. R.v.St., Tibax, nr. 20.599, 30 september I980; R.v.St., Zoete, nr. 22.446, 8 juli I 982.

78. Zie R.v.St., Bracke, nr. 20.324, I3 mei I980; R.v.St., Zoete, nr. 22.446, 8 juli I982; zie S. LUST, l.c., 2000, p. 223. 
eel bij de procedure voor de Raad van State tussengekomen partijen het recht hebben om het herstel van de wettigheid te vorderen na de nietigverklaring. Deze beperking vloeit voort uit de rechtspraak van de Raad van State volgens dewelke de onthouding van andere belanghebbenden om de nietigverklaring van de rechtshandeling te vorderen erop wijst dat zij in in het bestaan van de rechtshandeling berusten. ${ }^{79}$

Naast het erga omnes karakter van het vernietigingsarrest, kan worden gewezen op haar terugwerkende kracht $a b$ initio. Dit betekent dat afgezien van haar gevolgen voor de toekomst, zij eveneens gelding heeft voor het verleden, met als hoofdzakelijk gevolg dat de administratieve rechtshandeling wordt geacht nooit te hebben bestaan. ${ }^{80}$ Deze terugwerkende kracht is evenmin onbeperkt en moet worden getemperd. Immers, de terugwerkende kracht is slechts een fictie en de gevolgen van de vernietigde rechtshandeling kunnen niet volledig worden opgeheven. ${ }^{8 \mathrm{I}} \mathrm{Zo}$ zal, bij wijze van voorbeeld, een ambtenaar waarvan de benoeming werd vernietigd, in geen geval de ontvangen verloning moeten terugbetalen, aangezien niemand redelijkerwijze kan betwisten dat hij recht heeft op loon voor zijn geleverde prestaties. ${ }^{82}$ Evenzeer zullen de door de ambtenaar verrichte rechtshandelingen niet onwettig zijn door de loutere onregelmatigheid van de benoeming van hun auteur. Dit is een gevolg van de toepassing van de, uit het continuïteitsbeginsel voortvloeiende, theorie van de 'feitelijke ambtenaar'. ${ }^{83}$ Het voorgaande neemt niet weg dat in een gegeven geval met een beroep op artikel 159 van de Grondwet gevolgakten door de gewone rechter, onbeperkt in tijd, buiten toepassing moeten worden gelaten ook al werden zij niet vernietigd en is de vernietigingstermijn verstreken. ${ }^{84}$

Sedert het midden van de jaren negentig beschikt de Raad van State krachtens artikel I4ter R.v.St.-wet over de bevoegdheid om bij wijze van algemene beschikking de gevolgen van een vernietigde verordeningsbepaling aan te duiden die als gehandhaafd moeten worden beschouwd of voorlopig gehandhaafd moeten worden voor de termijn die hij vaststelt. Voordien had de Raad van State deze bevoegdheid niet. Toch werd een enkele keer beslist - en dan nog naar aanleiding van de vernietiging van een individueel benoemingsbesluit - dat de gevolgen van de vernietiging slechts werkzaam zouden worden op een welbepaalde (toekomstige) datum. Het betrof de vernietiging van een benoeming van een docent aan een universiteit. ${ }^{85}$

Artikel I4ter R.v.St.-wet werd ingevoegd om de nadelige gevolgen van de retroactieve werking van een vernietigingsarrest te beperken en om de daardoor ontstane rechtsonzekerheid enigszins te verzachten. Wanneer de Raad van State de gevolgen van de vernietiging in de tijd beperkt, moet de aanduiding van de te behouden rechtsgevolgen gebeuren 'bij wege van algemene beschikking', wat betekent dat de

79. A. Mast, J. Dujardin, M. Van Damme, J. Vande Lanotte, o.c., nr. 997, p. 97I; P. Lewalle, o.c., nr. 527 , p. 958 e.v.

8o. P. Lewalle, o.c., nr. 519, p. 935 .

8I. A. Alen, J. Dujardin, A. Mast, J. Vande Lanotte, o.c., nr. 999, p. 976.

82. M. Leroy, o.c., p. 735 .

83. Deze theorie dekt de gevallen waarin een rechtshandeling wordt gesteld door een persoon die niet de wettige ambtenaar is en wordt toegepast met het oog op het verzekeren van de continuïniteit van de openbare dienst en met toepassing van de schijnbare ambtelijkheid. M. Leroy, o.c., p. 737; P. Lewalle, o.c., nr. 522, p. 948.

84. Zie hierover o.m. S. Lust, l.c., p. 237 en de daar aangehaalde rechtspraak.

85. R.v.St., Heyndels, nr. 25.424, 3I mei I985. 
te behouden gevolgen als een abstracte categorie moeten worden aangeduid. Hij kan m.a.w. de toepassing van artikel I4ter niet beperken tot welbepaalde individuele gevolgen van de vernietigde handeling. Er mag voorts worden aangenomen dat de Raad van State een dergelijke ingreep motiveert. Er wordt aangenomen dat de Raad van State zijn bevoegdheid ex artikel I4ter enkel kan aanwenden wanneer vaststaat dat de vernietiging van het besluit bijzonder ernstige gevolgen zou hebben vanuit het oogpunt van de rechtszekerheid en dat hij daarbij 'op behoedzame wijze en met gezond verstand te werk moet gaan'. ${ }^{86}$

Artikel I4ter R.v.St.-wet bleef niet vrij van grondwettigheidskritiek omdat hierdoor de werking van artikel I59 (exceptie van onwettigheid) van de Grondwet wordt gefnuikt en, zodoende, het gelijkheidsbeginsel op het vlak van de rechtsbedeling wordt geschonden. ${ }^{87}$ Er is vast te stellen dat de Raad van State - die zulks ook ambtshalve kan doen - slechts zéér uitzonderlijk beslist om de gevolgen van de vernietiging in de tijd te beperken. Een zeldzaam voorbeeld betreft een geval waarin de Raad van State de Nederlandse en Franse versie van de Code van de Plichtenleer die op Io december 1994 was goedgekeurd door de Hoge Raad van de Orde van Dierenartsen vernietigde en besloot dat deze vernietiging omwille van de rechtszekerheid, eerst uitwerking had wanneer ze aan de partijen ter kennis was gebracht. ${ }^{88}$ In een ander arrest behoudt de Raad van State de gevolgen van het vernietigde gedeelte van het gewestplan van kracht moeten blijven voor de op het ogenblik van de vernietiging reeds afgeleverde vergunningen en voor aanvragen of beroepen die reeds bij de bevoegde overheid waren ingediend op diezelfde datum en dit 'gedurende de tijd die een naarsteg bestuur nodig heeft om zich opnieuw over de bestemming van het gebied uit te spreken'. 89

Ten slotte, wat de verplichtingen betreft die uit de vernietiging voortvloeien, wordt opgemerkt dat de auteur van de vernietigde rechtshandeling niet eenzelfde rechtshandeling mag stellen, zonder de onwettigheid te verbeteren die aanleiding heeft gegeven tot de nietigverklaring. ${ }^{90}$ Er valt eveneens op te merken dat wanneer een administratieve rechtshandeling vernietigd wordt, die handeling niet noodzakelijk moet worden vervangen door een andere. Voorts zalm de vernietiging veelal niet volstaan om rechtsherstel te verlenen en is bijkomend optreden van de overheid vereist om rechtsherstel te verlenen. Of de overheid er ingevolge een vernietigingsarrest toe gehouden is bijkomend rechtsherstel te bieden en wat de inhoud ervan moet zijn, hangt af van de aard van de vernietigde handeling, de feitelijke en juridische omstandigheden van het geval en de rechtsplicht die de overheid heeft geschonden. Een en ander zal moeten blijken uit de concrete vernietigingsgronden.

Het brengt ons meteen tot de vraag welke nog de rol van de Raad van State kan zijn bij onwil van het bestuur om rechtsherstel te verlenen. Er wordt immers traditioneel

86. A. Wirtgen, 'Bespreking van technieken van pragmatisch en billijk conflictbeheer door de Raad van State', in G. Debersaques e.a. (eds.), 4. Rechtsbescherming door de Raad van State. 15 jaar procedurele vernieuwing, Brugge, Die Keure, p. 290.

87. Zie hierover S. Lust, l.c., p. 243 e.v.; D. Renders, 'Le maintient des effets d'un règlement annulé par le Conseil d'Etat et le respect des droits fondamentaux', J.T., 2002, p. 762-763.

88. R.v.St., Fontaine, v.z.w. Belgische syndicale dierenartsenvereniging (B.S.D.V.) en Janssens, nr. 74.86I, 30 juni 1998.

89. R.v.St., Evrard, nr. 7I.610, 5 februari I998; R.v.St., Stad Waver, nr. 75.712, Io september 1998.

9o. M. Leroy, o.c., p. 7Io. 
aangenomen dat de Raad van State geen bevelen kan geven aan de overheid, geen schadevergoeding kan toekennen of de overheid tot het betalen daarvan kan veroordelen (behoudens in het kader van de rechtmatige overheidsdaad op grond van artikel II R.v.St.-wet) noch zich in de plaats kan stellen van de overheid door zelf de handeling te stellen waardoor het rechtsherstel kan worden verleend, etc.. Toch beschikt de Raad van State - hetgeen is toe te juichen zowel vanuit preventief als repressief oogpunt - met de mogelijkheid tot het opleggen van een dwangsom over een specifiek rechtsmiddel om de naleving van vernietigingsarresten af te dwingen (art. 36 R.v.St.wet) ${ }^{91,92}$. Voormeld artikel 36 bepaalt dat wanneer het herstel van de wettigheid inhoudt dat de vernietiging van een rechtshandeling gevolgd moet worden door een nieuwe overheidsbeslissing of overheidshandeling, bij ingebreke blijven van de overheid, de persoon op wiens verzoek de nietigverklaring is uitgesproken, de Raad van State kan verzoeken aan de betrokken overheid een dwangsom op te leggen. Hetzelfde kan geschieden wanneer uit een vernietigingsarrest voor de administratieve overheid een onthoudingsplicht ten aanzien van bepaalde beslissingen volgt. In voorkomend geval kan de Raad van State worden verzocht de overheid het bevel te geven, op verbeurte van een dwangsom, de beslissingen in te trekken die ze zou hebben genomen met schending van de uit het annulatiearrest volgende onthoudingsverplichting. Dergelijk verzoek is slechts ontvankelijk wanneer verzoeker de overheid bij een ter post aangetekende brief tot het nemen van een nieuwe beslissing heeft aangemaand en ten minste drie maanden vanaf de kennisgeving van het vernietigingsarrest verlopen zijn.

\section{Het verwerpingsarrest}

Het gezag van een verwerpingsarrest is relatief, zij geldt met andere woorden enkel ten aanzien van de partijen die betrokken waren bij het geschil93 en slechts voor die rechtsvragen die werkelijk werden opgeworpen en beslecht. 94

Het verwerpingsarrest verandert, in theorie, niets aan het rechtsverkeer. Het arrest heeft geen rechtsgevolgen ten aanzien van derden (voor wie het een res inter alios acta is) wat de wettigheid van de rechtshandeling betreft, en dit ongeacht of de verwerping werd uitgesproken op basis van de onontvankelijkheid van het verzoekschrift, of op basis van een uitspraak ten gronde. ${ }^{95}$ De rechtshandeling krijgt geen wettigheidscertificaat en is niet beschermd tegen nieuwe vernietigingsberoepen op grond van andere middelen (indien dit evenwel nog mogelijk zou zijn gezien de beroepstermijnen voor de Raad van State), noch is zij immuun voor gebeurlijke excepties van onwettigheid die opgeworpen worden voor andere rechtscolleges.

9I. Een dwangsom kan ook worden opgelegd in het kader van het administratief kort geding, bij het bevelen van een schorsing en/of het opleggen van voorlopige maatregelen (art. 17, § 5 en I8, vijfde lid, R.v.St.-wet) of, nog bij het niet - indienen van het administratief dossier (art. 2I R.v.St.-wet).

92. Zie hierover I. Opdebeek, 'De Raad van State en de dwangsom', in: 4. Rechtsbescherming door de Raad van State. 15 jaar procedurele vernieuwing, l.c., p. 3 I8 e.v.

93. M. Leroy, o.c., p. 70I; zie ook Cass. 9 januari I997, A.J.T. I998-99, I25, noot J. THEUNIS; vergelijk Cass., 8 juni I984, Arr. Cass., I983-84, I327.

94. R. Witmeur, 'L'autorité de la chose jugée administrativement', in: X. (ed.), Le Conseil dEtat de Belgique. Cinquante ans après sa création (1946-1996), Brussel, Bruylant, I999, p. 783.

95. M. Leroy, o.c., p. 699. 
Ten gevolge van een verwerpingsarrest is enkel de situatie ten aanzien van de betrokken partijen gewijzigd, en dan nog in een mate die verschilt naargelang het rechtscollege waarvoor men verschijnt. De burgerlijke rechter oordeelt immers dat een rechtsvraag die hem wordt voorgelegd nooit identiek hetzelfde voorwerp kan hebben als een vernietigingsberoep (aangezien het om twee contentieux gaat die een noodgedwongen onderscheiden voorwerp hebben) en niet van dien aard kan zijn dat een reeds door de Raad van State beslecht debat nog eens zou worden overgedaan voor een ander rechtscollege. ${ }^{96}$

\subsubsection{Eenheid in de rechtspraak: De techniek van de prejudiciële vraag en het streven naar eenheid binnen de Afdeling Bestuursrechtspraak}

1 De techniek van de prejudiciële vraag.

België kent geen stelsel van bestuursrechtspraak dat in de mogelijkheid voorziet (zie evenwel nog infra) om aan eigen hoogste bestuursrechters, welke dan ook, prejudiciële vragen te stellen. Daarentegen bestaat uiteraard wel de mogelijkheid om vragen te stellen aan het Hof van Justitie of het Benelux Gerechtshof of nog de mogelijkheid zelfs de plicht om prejudiciële vragen te stellen aan het Grondwettelijk Hof.97 Voorts doet op vraag van de verzoeker de algemene vergadering van de Afdeling Bestuursrechtspraak van de Raad van State, bij wijze van prejudiciële beslissing uitspraak over vragen omtrent de schending van het grondwettelijk gelijkheidsbeginsel door een akte of een verordening van een administratieve overheid.

In het kader van dit preadvies wordt enkel nader ingegaan op de techniek van de prejudiciële vragen die aan het Hof van Justitie van de Europese Gemeenschappen, het Grondwettelijk Hof en de algemene vergadering worden gesteld. ${ }^{8}$

\section{a Prejudiciële vragen aan het Hof van Justitie van de Europese Gemeenschappen}

De Raad van State is een rechtscollege waarvan de beslissingen definitief zijn in die zin dat ze niet meer vatbaar zijn voor een jurisdictioneel beroep in het interne recht. Overeenkomstig artikel 234 van het E.G.- Verdrag, is de Raad van State er bijgevolg - in tegenstelling tot de lagere rechtscolleges - toe gehouden om aan het Europees Hof van Justitie alle vragen te stellen met betrekking tot de uitlegging van het Verdrag evenals de geldigheid en de uitlegging van de handelingen van de instellingen van de Gemeenschap en van de Europese Centrale Bank, alsmede over de uitlegging van de statuten van bij besluit van de Raad ingestelde organen, wanneer die statuten daarin voorzien. 99

96. M. Leroy, o.c., p. 705 .

97. Ibidem.

98. Er moet evenwel worden opgemerkt dat ook andere prejudiciële vragen kunnen worden gesteld. Bij voorbeeld bij het Benelux-Gerechtshof. Sommige geschillen kunnen dan weer enkel worden gebracht voor een rechtscollege dat speciaal daartoe bevoegd is. Zo zijn bijvoorbeeld enkel de burgerlijke rechtscolleges bevoegd om kennis te nemen van schriftvervalsing. In de hypothese dat een voorgelegd stuk beticht wordt van valsheid, moet de Raad van State, in beginsel, zijn uitspraak aanhouden tot het bevoegde rechtscollege zich hierover heeft uitgesproken.

99. A. Mast, J. Dujardin, M. Van Damme, J. Vande Lanotte, o.c., nr. I038, p. Iog6. 
Deze procedure wil de eenheid van toepassing van het communautair recht verzekeren en brengt tevens zo weinig mogelijk de bevoegdheden van de nationale rechter in het gedrang. Het principieel stringente karakter van de verplichting dient dan ook te worden genuanceerd.

Uit de rechtspraak blijkt dat de Raad van State het Hof van Justitie niet moet raadplegen wanneer de hij in een arrest van het Hof van Justitie de gegevens vindt die het mogelijk maken het gemeenschapsrecht te interpreteren of, nog, wanneer de juiste toepassing van het gemeenschapsrecht zo evident is dat redelijkerwijze geen ruimte voor twijfel kan bestaan of indien het antwoord op de prejudiciële vraag niet dienend is. Enerzijds, wordt immers niet betwist dat de nationale rechter de noodzaak van de vraagstelling mag beoordelen: de noodzaak om een supranationale norm toe te passen waarvan de draagwijdte betwist is, vormt het determinerend criterium om het Hof te vatten. ${ }^{\text {IOO }}$ Anderzijds, rijst de vraag of deze verplichting bestaat wanneer de opgeworpen 'vraag' niet onontbeerlijk is voor de oplossing van het geschil. Het Hof van Justitie van de Europese Gemeenschappen erkent inderdaad omstandigheden waarin de hoogste rechtscolleges niet meer verplicht zijn om een prejudiciële vraag te stellen, met name, enerzijds, wanneer het Hof reeds uitspraak heeft gedaan op een vraag met een identiek onderwerp en, anderzijds, wanneer er redelijkerwijze geen twijfel bestaat omtrent de interpretatie die moet worden gegeven aan de rechtsnorm.

In uitvoering van artikel 234 van het E.G.-Verdrag, heeft de Raad van State reeds bij verschillende gelegenheden een prejudiciële vraag gesteld aan het Hof. Evenwel, is het geen courante gebeurtenis. ${ }^{\text {IOI }}$ Voorts heeft de Raad van State, voor zover ons bekend is, in het kader van korte gedingprocedures nog geen prejudiciële vraag gesteld aan het Hof van Justitie. Hij verwijst daartoe o.m. naar de mogelijkheid van het stellen van dergelijke vraag in de vernietigingsprocedure of naar de snelheid waarmee hij in de fase van het kort geding moet optreden. ${ }^{\text {IO2 }}$

\section{b Prejudiciële vragen aan het Grondwettelijk $\mathrm{Hof}^{103}$}

Het voorwerp van de prejudiële vragen gericht aan het Grondwettelijk Hof is van tweeërlei aard. Het Grondwettelijk Hof is immers als énige bevoegd om kennis te nemen van onregelmatigheden van wetskrachtige normen en dit ten aanzien van, enerzijds, de regels die de onderscheiden bevoegdheden van de Staat, de Gemeenschappen en de Gewesten bepalen en, anderzijds, de fundamentele rechten en vrijheden gewaarborgd in Titel II van de Grondwet (artikelen 8 tot en met 32) en van de artikelen 170 (legaliteitsbeginsel in belastingszaken), I72 (gelijkheid in fiscale zaken) en I9I (bescherming voor vreemdelingen). De prejudiciële beslissingen betreffen derhalve niet alleen de schending door een wet, decreet of ordonnatie van de bevoegdheidsregels, de grondwettelijke rechten en vrijheden en de artikelen I70,

ıоo. M. Leroy, o.c., p. 6o6; A. Mast, J. Dujardin, M. Van Damme, J. Vande Lanotte, o.c., nr. Io38, p. 1097.

Ior. A. Mast, J. Dujardin, M. Van Damme, J. Vande Lanotte, o.c., nr. I038, p. Iog6 en de daar geciteerde gevallen.

I02. R.v.St., VT4 Limited, nr. 83.639, 25 november I999; R.v.St., Pozarowsky, nr. 52.63I, 3 april I995.

I03. Wat dit onderwerp betreft, zie, in het bijzonder X (ed.), De verhouding tussen het Grondwettelijk Hof, de Rechterlijke Macht en de Raad van State, Brugge, Die Keure, 2006. 
I72 en I92I van de Grondwet maar ook eventuele normenconflicten zonder bevoegdheidsoverschrijding (de zgn. antinomieën).

Alle rechtscolleges, ook de hoogste, zijn vrijgesteld van het stellen van een prejudiciële vraag aan het Hof wanneer de zaak niet door het betrokken rechtscollege kan worden behandeld om redenen van onbevoegdheid of niet-ontvankelijkheid, tenzij wanneer die redenen ontleend zijn aan normen die zelf het onderwerp uitmaken van het verzoek tot het stellen van de prejudiciële vraag. ${ }^{\text {I04 }} \mathrm{Zij}$ zijn eveneens niet toe gehouden om een prejudiciële vraag te stellen wanneer het Grondwettelijk Hof reeds uitspraak heeft gedaan op een vraag of een beroep met een identiek onderwerp. ${ }^{\text {I05 }}$

Buiten deze gevallen om, zijn de rechtscolleges waarvan de beslissingen niet meer vatbaar zijn voor een jurisdictioneel beroep, te weten het Hof van Cassatie en de Raad van State, in beginsel, verplicht om een prejudiciële vraag te stellen aan het Grondwettelijk Hof wanneer één der partijen hierom verzoekt. ${ }^{106}$ In het licht van het voorgaande is de Raad van State er bijgevolg ook toe verplicht om een prejudiciële vraag te stellen wanneer de wet, het decreet of de in artikel I34 van de Grondwet bedoelde regel een regel of een artikel van de Grondwet bedoeld in $§$ I klaarblijkelijk niet schendt; of wanneer hij meent dat het antwoord op de prejudiciële vraag niet onontbeerlijk is om uitspraak te doen. ${ }^{\text {I07 }}$ De bijzondere wet van 9 maart 2003 preciseerde dat - en zulks geldt ook voor het administratief kort geding bij de Raad van State behalve wanneer ernstige twijfel bestaat over de verenigbaarheid van een wet, een decreet of een in artikel I34 van de Grondwet bedoelde regel met een van de in § I bedoelde regels of artikelen van de Grondwet en geen vraag of beroep met hetzelfde onderwerp bij het Hof aanhangig is, een rechtscollege in het geval de vordering spoedeisend is en de uitspraak over de vordering slechts een voorlopig karakter heeft, er niet toe gehouden is een prejudiële vraag te stellen (art. $26, \S 3$ B.W.H.I.) ${ }^{\text {I08 }}$

De beschreven situatie stuit soms op kritiek, zeker wat de laatste hypothese betreft, omdat deze ertoe noopt om het Grondwettelijk Hof te vatten zelfs indien een ander middel op zichzelf genomen reeds van aard is om de nietigverklaring te verkrijgen. De rechtspraak lijkt deze weg evenwel niet (altijd) te volgen aangezien er arresten bestaan waar er geen prejudiciële vraag werd gesteld wanneer de vraagstelling 'niet nuttig bleek voor de oplossing van het geschil'. ${ }^{\text {IO9 }}$ Meer algemeen heeft de Raad van State een vindingrijke rechtspraak die toelaat om de vraagstelling aan het

I04. Artikel 26, § 2, lid 2, $I^{\circ}$ van de Bijzondere wet van 6 januari ig89 op het Grondwettelijk Hof.

I05. Artikel 26, § 2, lid 2, $2^{\circ}$ van de Bijzondere wet van 6 januari ig89 op het Grondwettelijk Hof. Vóór de inwerkingtreding van de Bijzondere Wet van 9 maart 2003 tot wijziging van de Bijzondere wet van 6 januari 1989 , konden de rechtscolleges waarvan de beslissingen niet aanvechtbaar waren in beroep, geen prejudiciële vraagstelling weigeren op deze grond. Thans, is de exceptie eveneens op hen toepasselijk.

Io6. Zie artikel 26, \ 2, lid 2, $2^{\circ}$ van de Bijzondere wet van 6 januari 1989 op het Grondwettelijk Hof.

I07. In beide gevallen zijn de rechtscolleges waarvan de beslissingen vatbaar zijn voor beroep, niet verplicht om een prejudiciële vraag te stellen aan het Grondwettelijk Hof.

I08. Zie hierover D. D'Hooghe en L. Schellekens, 'De interferentie tussen kortgedingprocedures voor de Raad van State en gerechtelijke procedures voor andere rechtsmachten', in: Administratieve rechtsbibliotheek. 4. Rechtsbescherlming door de Raad van State, 15 jaar procedurele vernieuwing, l.c., p. 248 e.v.

Io9. M. Leroy,o.c., p. 632. 
Grondwettelijk Hof in menig geval te omzeilen. ${ }^{\text {IIO }}$ Aldus bijvoorbeeld zag de Raad van State af van het stellen van een prejudiciële vraag nu een prejudiciële vraag die niet de openbare orde raakt om proceseconomische redenen en omwille van het vereiste van wapengelijkheid van de procespartijen, in limine litis moet worden geformuleerd of, minstens, in het eerste processtuk waarin de bedoelde partij dit vermocht te doen. ${ }^{\text {III }}$

Tegen de beslissing van de Raad van State om een prejudiciële vraag aan het Hof voor te leggen kan geen enkel rechtsmiddel worden aangewend. Tegen de weigering om een vraag te stellen kan geen afzonderlijk rechtsmiddel worden aangewend. De weigeringsbeslissing moet worden bestreden met de eindbeslissing van het betrokken rechtscollege. ${ }^{\mathrm{II} 2}$ In ieder geval, moet de beslissing waarbij een rechtscollege weigert een prejudiciële vraag te stellen de redenen van de weigering aangeven. ${ }^{\mathrm{II} 3}$

Ten slotte, in het geval dat een prejudiciële vraag wordt gesteld aan het Grondwettelijk Hof, zal het gewezen arrest gezag van gewijsde hebben in het voorliggende geschil; het arrest regelt het conflict of beantwoordt de vraag van de wettelijkheid, waarna het rechtscollege dat de vraag heeft gesteld zich naar het arrest zal schikken bij het nemen van haar eindbeslissing.

\section{c Prejudiciële vragen aan de Algemene Vergadering}

Op vraag van de verzoeker die ten laatste diende te gebeuren bij het indienen van zijn memorie van wederantwoord deed de algemene vergadering van de afdeling administratie, bij wijze van prejudiciële beslissing, uitspraak over vragen omtrent de schending van de artikelen Io, II en 24 van de Grondwet door een akte of verordening van een administratieve overheid. Wanneer een dergelijke vraag werd opgeworpen voor een kamer waarbij een aanunulatieberoep was ingesteld, moest deze de algemene vergadering verzoeken daarover uitspraak te doen. Aan deze mogelijkheid is echter recent een einde gesteld (art. 49 van de Wet van 15 september 2006 tot hervorming van de Raad van State en tot oprichting van een Raad voor Vreemdelingenbetwistingen. Ook al waren de arresten in dat verband bijzonder schaars, dan werd de mogelijkheid tot interne verwijzing die voor de verzoeker openstond in de praktijk als omslachtig ervaren en niet zonder risico op dilatoire gevolgen.

\section{d Eenheid in de rechtspraak}

Het zijn niet de gedingvoerende partijen doch enkel de eerste voorzitter van de Raad van State die, overeenkomstig artikel 92 R.v.St.-wet, hetzij op eigen initiatief of op dat van de auditeur-generaal, de verwijzing van een zaak naar de algemene vergadering kan bevelen teneinde de eenheid van de rechtspraak te verzekeren. ${ }^{\text {II4 }}$

IIo. Zie wat dat onderwerp betreft P. Boucquey, 'La jurisprudence du Conseil d'Etat en matière de questions préjudicielles à la Cour d'arbitrage', in: X. (ed.), De verhouding tussen het Grondwettelijk Hof, de Rechterlijke Macht en de Raad van State, Brugge, Die Keure, 2006, p. 206 e.v.

III. R.v.St., van Labeke en De Vos, nr. I43.87I, 28 april 2005.

II2. De Raad van State zag reeds af van een prejudiciële vraagstelling indien deze de rechtsmacht van de Raad van State betreft en zijn beslissing hierover vatbaar is voor een voorziening in cassatie: R.v.St., Godts, nr. I30.075n, 2 april 2004.

II3. A. Mast, J. Dujardin, M. Van Damme, J. Vande Lanotte, o.c., nr. I040, p. IIO2.

II4. R.v.St., Beckers, nr. I40.732, I6 februari 2005, R.W. 2005-2006, p. I665-I668, noot S. Boullart. 


\subsection{De schorsingsbevoegdheid van het objectief contentieux}

\subsubsection{De toepassingsvoorwaarden}

De schorsingsbevoegdheid is een accessorium van de vernietigingsbevoegdheid en laat toe om de tenuitvoerlegging van de akten of reglementen waarvan de vernietiging wordt gevraagd te schorsen mits aan twee cumulatieve grondvoorwaarden is voldaan, met name, dat ernstige middelen wordt aangevoerd en dat de tenuitvoerlegging van de reglementen of akten een moeilijk te herstellen ernstig nadeel kan berokkenen. ${ }^{\text {II } 5}$

Bijkomend kan een onderscheid worden gemaakt tussen de schorsing bij uiterst dringende noodzakelijkheid en de gewone schorsing. De schorsing bij uiterst dringende noodzakelijkheid heeft een uitzonderlijk en ongewoon karakter omdat de schorsing bij voorraad kan worden bevolen, zonder dat de partijen of sommige van hen worden gehoord. Bij deze procedure worden de rechten van verdediging van de verwerende en de tussenkomende partij tot een minimum herleid en wordt het normaal verloop van de rechtspleging voor de Raad van State verstoord. ${ }^{\text {II6 }}$ Beide procedures worden gekenmerkt door korte termijnen.

Het voorwerp van het schorsingsberoep is hetzelfde als bij de procedure tot vernietiging, met name eenzijdige administratieve rechtshandelingen van Belgische administratieve overheden. evenals akten en reglementen van de wetgevende vergaderingen of van hun organen daarbij inbegrepen de ombudsmannen ingesteld bij deze assemblees, van het Rekenhof en van het Grondwettelijk Hof, van de Raad van State en de administratieve rechtscolleges evenals van organen van de rechterlijke macht en van de Hoge Raad voor de Justitie met betrekking tot overheidsopdrachten en leden van hun personeel. ${ }^{\text {II7 }}$

Ook impliciet afwijzende beslissingen zijn vatbaar voor schorsing. ${ }^{\text {II } 8}$

Onder ernstige middelen worden verstaan, middelen die op het eerste gezicht, gelet op de omstandigheden van de zaak, ontvankelijk en gegrond kunnen zijn en bijgevolg tot de vernietiging van de bestreden rechtshandeling kunnen leiden. ${ }^{\text {II } 9}$

Het bestaan van een moeilijk te herstellen ernstig nadeel wordt door de Raad van State in concreto beoordeeld aan de hand van de uiteenzetting van de feiten in het verzoekschrift. Er moet een voldoende causaal verband bestaan tussen het mogelijk nadeel en de bestreden bestuurshandeling. ${ }^{\mathrm{I2O}}$ Bovendien moet het nadeel door de onmiddellijke tenuitvoerlegging van de bestreden akte of het reglement berokkend worden. Evenwel volstaat reeds een risico op een nadeel. ${ }^{\mathrm{I} 2 \mathrm{I}}$ Een geldelijk nadeel of het derven van een financieel voordeel is in beginsel niet voldoende om te kunnen spreken van een moeilijk te herstellen ernstig nadeel. ${ }^{\text {I22 }}$

II5. A. Mast, J. Dujardin, M. Van Damme, J. Vande Lanotte, o.c., p. Ior3.

II6. A. Mast, J. Dujardin, M. Van Damme, J. Vande Lanotte, o.c., p. I03I-I032.

II7. A. Mast, J. Dujardin, M. Van Damme, J. Vande Lanotte, o.c., p. 973-979.

II8. Arbitragehof nr. I9I/2004, 24 november 2004.

II9. A. Mast, J. Dujardin, M. Van Damme, J. Vande Lanotte, o.c., p. IoI4.

I20. A. Mast, J. Dujardin, M. Van Damme, J. Vande Lanotte, o.c., p. IoI7.

I2I. A. Mast, J. Dujardin, M. Van Damme, J. Vande Lanotte, o.c., p. IoI4 en Ior6.

I22. A. Mast, J. Dujardin, M. Van Damme, J. Vande Lanotte, o.c., p. IoI5. 
Naast de bevoegdheid om te schorsen is de Raad van State bevoegd om, met uitzondering van de maatregelen die betrekking hebben op de burgerlijke rechten, alle nodige maatregelen te bevelen teneinde de belangen van de partijen of andere belanghebbenden veilig te stellen. ${ }^{123}$

\subsubsection{De rol van de partijen}

Hiervoor wordt verwezen naar de uiteenzetting bij het vernietigingsberoep.

Bijkomend kan worden opgemerkt dat de verzoekende partijen sinds de recente wetswijziging ${ }^{\mathrm{I} 24}$ van 15 september 2006 hun vorderingen tot schorsing en vernietiging met éénzelfde akte moeten instellen. Wel is vereist indien ook een schorsing wordt gevraagd dat het opschrift van de akte uitdrukkelijk vermeld dat eveneens een vordering tot schorsing wordt ingesteld. Bij ontstentenis van het vervullen van deze pleegvorm, zal enkel de vordering tot vernietiging worden weerhouden. Het vereiste van de enige akte geldt evenwel niet voor de vordering tot schorsing bij uiterst dringende noodzakelijkheid. ${ }^{125}$

Naast een aantal vermeldingen die het verzoekschrift tot nietigverklaring ook dient te vermelden, zal de vordering tot schorsing een uiteenzetting van de feiten en de middelen bevatten die het bevelen van de schorsing rechtvaardigen en in voorkomend geval, van de feiten die de uiterst dringende noodzakelijkheid rechtvaardigen. ${ }^{126}$

Specifiek voor de schorsingsprocedure is dat alle partijen op de terechtzitting moeten verschijnen of moeten vertegenwoordigd zijn. Indien de eiser niet verschijnt, noch vertegenwoordigd is, wordt de vordering afgewezen. Verschijnt de verwerende partij niet, dan wordt deze geacht in te stemmen met de vordering. Dit betekent evenwel niet dat de vordering in dat geval automatisch wordt toegewezen. De Raad van State zal nog steeds nagaan of aan de schorsingsvoorwaarden is voldaan. ${ }^{\text {I27 }}$

\subsubsection{De opdracht van de Raad van State}

Hiervoor kan ook worden verwezen naar hetgeen hoger is gesteld is gesteld in het kader van de vernietigingsprocedure.

Daarnaast kan nog worden vermeld dat er in het kader van het kortgeding meer ruimte lijkt voor mondelinge toelichting tijdens de pleitzitting mede gegeven de snelheid en korte termijn waarbinnen de schriftelijke procedure moet worden gevoerd, inzonderheid wat de verwerende partij betreft al is ook daaraan (licht) verholpen met de recente wetswijzigingen van 5 september 2006. De Raad van State moet uit het (nader toegelichte) feitenrelaas afleiden of er ernstige middelen zijn, of

I23. A. Mast, J. Dujardin, M. Van Damme, J. Vande Lanotte, o.c., p. Ior2.

I24. Wet vani5 september 2006 tot hervorming van de Raad van State en tot oprichting van een Raad voor Vreemdelingenbetwistingen (B.S. 6 oktober 2006).

I25. A. Mast, J. Dujardin, M. Van Damme, J. Vande Lanotte, o.c., p. I039-Io40.

I26. A. Mast, J. Dujardin, M. Van Damme, J. Vande Lanotte, o.c., p. I022.

I27. A. Mast, J. Dujardin, M. Van Damme, J. Vande Lanotte, o.c., p. I025. 
voldaan is aan de vereiste van het moeilijk te herstellen ernstig nadeel en of er desgevallend sprake is van uiterst dringende noodzakelijkheid.

Voorts zal de Raad van State in het kader van een schorsingsonderzoek in een eerste instantie nagaan of de voorwaarden voor de schorsing vervuld zijn. Is dat niet het geval, dan zal de Raad van State de excepties en middelen slechts summier onderzoeken of zelfs helemaal niet. ${ }^{\text {I } 8}$

Wat de uiteenzetting der middelen betreft, vereist de Raad van State van de verzoekende partij, dat zij het formuleren van haar middelen tot het essentiële beperkt, hetgeen impliceert dat zij zeer nauwkeurig moet aanvoeren welke precieze rechtsregel of rechtsbeginsel zij geschonden acht en al even nauwkeurig moet vermelden waarin de schending precies bestaat. ${ }^{129}$ De vereiste van duidelijkheid geldt des te meer bij een procedure tot schorsing bij uiterst dringende noodzakelijkheid. Evenwel menen sommige auteurs ${ }^{\mathrm{I} 30}$ dat bij de beoordeling van de ernst rekening moet worden gehouden met het feit dat de verzoekende partij bij het instellen van zijn vordering mogelijks nog geen kennis had van het administratief dossier.

De vraag rijst hoe een en ander in de toekomst zal evolueren. Immers, artikel van de wet van 5 septemver 2006 voorziet dat thans dat, in het kader van het 'gewone' kortgeding, schorsing en vernietiging in eenzelfde akte moeten worden gevraagd wat meteen de vraag doet rijzen of het onderscheid wordt behouden tussen middelen voor schorsing en middelen tot vernietiging.

Gaat de Raad van State over tot een onderzoek van de middelen, dan neemt hij geen middelen in aanmerking die niet in het inleidende verzoekschrift werden aangevoerd. Zo ook geen middelen die de verzoekende partij niet eerder kon aanvoeren omdat ze gesteund zijn op gegevens die haar slechts na het neerleggen van haar verzoekschrift bekend zijn geworden, noch ernstige middelen van openbare orde. ${ }^{\mathrm{I}}{ }^{\mathrm{I}}$ De Raad van State meent dat de inroeping van nieuwe middelen de urgente afwikkeling van de rechtszaak verstoort en de rechten van verdediging van verwerende partij beknot. Deze jurisprudentiële regel wordt in de rechtsleer evenwel bekritiseerd. ${ }^{\mathrm{I}}{ }^{2}$

Wat het onderzoek naar de ernstige middelen betreft, volstaat één enkel ernstig middel, zo ook de andere voorwaarden vervuld zijn, om de schorsing te verkrijgen. De Raad van State dient dus in beginsel niet na te gaan of ook de andere opgeworpen middelen ernstig zijn. ${ }^{\text {I33 }}$

In kort geding kan en mag de Raad van State alleen onderzoeken of de middelen of het eerste gezicht gegrond lijken. Dit betekent dat het ernstig karakter van een middel na een eerste lezing evident moet blijken, zonder een langdurig en nauwgezet onderzoek. ${ }^{\text {I34 }}$ De praktijk leert echter dat Raad van State de ernst van de midde-

I28. J. Baert, G. Debersaques, Raad van State Afdeling Administratie. Ontvankelijkheid, Brugge, Die Keure, I996, p. Io.

I29. A. Wirtgen, l.c., p. 447 .

I30. A. Wirtgen, l.c., p. 447; E. Lancksweerdt, Het administratief kort geding, Deurne, Kluwer, I993, p. 87.

I3I. A. Wirtgen, l.c., p. 492. Deze auteur haalt een arrest aan waarin de Raad van State ook al anders heeft beslist m.b.t. een middel van openbare orde dat de verzoekers ter terechtzitting hebben aangevoerd.

132. A. Wirtgen, l.c., p. 49I.

I33. G. Debersaques, M. Van Damme, e.a. (eds.), Rechtsbescherming door de Raad van State. 15 jaar procedurele vernieuwing, Brugge, Die Keure, 2004, p. IIo; A. Wirtgen, l.c., p. 444.

I34. A. Wirtgen, l.c., p. 446 . 
len vrij streng beoordeelt. De Raad van State beperkt zich veelal niet tot een prima facie-onderzoek, maar onderzoekt de middelen vrij grondig. Het gebeurt eerder zelden dat een middel dat ernstig wordt bevonden, naderhand als niet gegrond wordt afgewezen. ${ }^{\text {I35 }}$

Het ambtshalve onderzoek van een middel is in beginsel enkel mogelijk in het kader van een vernietigingsprocedure. ${ }^{136}$ Evenwel, heeft de Raad van State ook in het kader van het schorsingscontentieux, bij wijze van uitzondering, reeds ambtshalve ernstige middelen van openbare orde onderzocht wanneer de gepleegde onwettigheid derwijze duidelijk is dat zij geen langdurig en nauwgezet onderzoek vereist en over alle aspecten ervan ter terechtzitting mondelinge debatten kunnen worden gevoerd. ${ }^{\mathrm{I}} 37$

Een schorsingsarrest heeft, zoals een vernietigingsarrest, gezag van gewijsde erga omnes. Dat betekent dat de uitspraak voorlopig - in afwachting van een eindarrest als waarheid geldt en dat het door de administratieve rechter prima facie beslechte rechtspunt in het kader van het administratief kort geding niet opnieuw in vraag kan worden gesteld, behoudens in geval van een verzoek tot intrekking of wijziging bedoeld in artikel I7, $\$ 2$, al. 3, R.v.St.-wet. Wordt de schorsing bevolen dan verliest de handeling haar uitvoerbaarheid niet enkel ten aanzien van de betrokken overheid maar ten aanzien van eenieder dus ook ten aanzien van belangehebbende derden. Toch zijn de gevolgen van een schorsingarrest beperkt want de gevolgen ervan gelden ex nunc. Het heeft geen terugwerkende kracht. ${ }^{13^{8}}$ Hoewel het schorsingsarrest strikt genomen geen terugwerkende kracht heeft, bezit het desalniettemin een declaratief karakter in de mate dat het erkent dat minstens één van de middelen ernstig is en dat, onder voorbehoud van een diepergaand onderzoek, de rechtshandeling aangetast is door een onwettigheid ook al wordt de bodemrechter er niet door gebonden. ${ }^{\mathrm{I} 9}$ Het gezag van gewijsde van een arrest dat een beroep tot schorsing verwerpt, is, net zoals een arrest dat een beroep tot nietigverklaring verwerpt, relatief van aard. ${ }^{\mathrm{I}}{ }^{\mathrm{O}}$

Bijzondere vermelding verdient nog de vordering tot het opleggen van voorlopige maatregelen. Krachtens artikel I8 R.v.St.-wet, kan de Raad van State wanneer bij hem overeenkomstig artikel $\mathrm{I} 7$ een vordering tot schorsing van een akte of een reglement aanhangig wordt gemaakt, als enige, bij voorraad en onder de in artikel $17, \S 2$, eerste lid, bepaalde voorwaarden, alle nodige maatregelen bevelen om de belangen van de partijen of van de personen die belang hebben bij de oplossing van de zaak veilig te stellen, met uitzondering van de maatregelen die betrekking hebben op de burgerlijke rechten. Uit deze bepaling volgt dat de vordering tot het bevelen van voorlopige maatregelen een accessorium is van de vordering tot schorsing die op haar beurt een accessorium is van de vordering tot vernietiging. Tegen een arrest waarbij uitspraak wordt gedaan over het verzoek tot het bevelen van voorlopige maatregelen staat geen verzet

I35. G. Debersaques, M. Van Damme e.a. (eds), o.c., p. Io6.

I36. A. Mast, J. Dujardin, M. Van Damme, J. Vande Lanotte, o.c., p. IO2I (voetnoot 3II).

I37. A. Wirtgen, l.c., p. 492.

I38. M. Leroy, o.c., p. 827 .

I39. E. Lanksweerdt, o.c., p. 22 en de verwijzingen daar; M. LEROY, o.c., p. 828.

I40. M. Leroy, o.c., p. 828 . 
of derdenverzet open. Een beroep tot herziening is evenzeer uitgesloten. Het enige rechtsmiddel dat wordt voorzien, is het verzoek tot intrekking of wijziging, welk verzoek enkel kan uitgaan van de partijen. De Raad van State is niet bevoegd om zich door het opleggen van een voorlopige maatregel in de plaats van de overheid te stellen en om in haar plaats te beslissen. ${ }^{\mathrm{I}}{ }^{\mathrm{I}} \mathrm{Hij}$ kan aan de verzoeker immers niet meer geven dan wat deze in een vernietigingsarrest kan bekomen. ${ }^{\mathrm{I}}{ }^{2}$

Punt van discussie is de vraag naar belangenafweging in het kader van het administratief kortgeding bij de Raad van State. Hoewel dat niet met zoveel woorden blijkt uit de R.v.St.-wet, blijkt uit de rechtspraak van de Raad van State dat deze zich niet zonder meer verplicht acht de vordering van verzoeker in te willigen wanneer aan alle voorwaarden van de schorsing is voldaan (de aanwezigheid van een ernstig middel, een MTHEN en, in voorkomend geval, het voorhanden zijn van uiterst dringende noodzakelijkheid). De Raad van State oordeelt derhalve dat het de belangen van de betrokken partijen kan afwegen en oordelen dat de belangen van de verwerende partij en/of de tussenkomende partij voorrang hebben boven het MTHEN van de verzoekende partij. In voorkomend geval zal de vordering tot schorsing om die reden worden afgewezen of kunnen de gevolgen van de schorsing worden beperkt. Aldus besliste de Raad van State in het arrest KRIER dat het gevaar voor de openbare gezondheid en veiligheid groter was dan het nadeel van verzoekster haar onbewoond verklaard huis te moeten verlaten en besloot hij dat dwingende redenen van algemeen belang zich verzetten tegen de schorsing van de tenuitvoerlegginging van het bestreden besluit ook al waren de grondvoorwaarden daartoe vervuld. ${ }^{\mathrm{I}}{ }^{4}$

In de rechtsleer worden twee vormen van belangenafweging onderscheiden. De eerste bestaat erin dat de Raad van State de ernst van het door de verzoeker ingeroepen nadeel - relativeert - door het nadeel dat anderen (ook eventuele derden) in geval van schorsing zouden ondervinden. De tweede vorm is gebaseerd op de idee dat de schorsing voor de Raad van State slechts een mogelijkheid is en daartoe niet is verplicht zelfs wanneer aan alle voorwaarden is voldaan.

Op de belangenafweging door de Raad van State in het kader van een schorsingsprocedure is ook scherpe kritiek geuit omdat het niet verenigbaar zou zijn met het objectief karakter van het beroep wegens machtsoverschrijding en met de primordiale rechtsbescherming van de burger tegen onrechtmatig overheidsoptreden. Enkel wanneer er een, dreigend gevaar bestaat voor een ernstige aantasting van de openbare orde zou de Raad mogen weigeren om te schorsen. De belangenafweging zou ook het gevaar inhouden van een 'gouvernement des juges' en leiden tot een zekere mate van subjectiviteit. ${ }^{\mathrm{I}} 44$ Anderen oordelen dan weer dat de belangenafweging een pragmatisch en billijk confictbeheer ten goede kan komen en op voorwaarde dat

I4I. R.v.St., Verlinde, nr. 39.036, 20 maart 1992 (betreffende de verplichting tot tewerkstelling van een OCMW- ambtenaar wiens tijdelijke aanstelling niet werd verlengd); R.v.St., Derudder, nr. 92.026, 9 januari 200I (betreffende de verplichting tot inschrijving van een student die in het vorig jaar ten onrechte als niet geslaagd werd gerangschikt); R.v.St., Pijls, nr. 39.7I4, I2 juni I 992 en R.v.St., Del Zingaro, nr. 48.204, 24 juni I994 en nr. 48.929, 6 september I994 (betreffende de stilleg van werken)

I42. A. Mast, J. Dujardin, M. Van Damme, J. Vande Lanotte, o.c., p. I035 en de daar geciteerde rechtspraak.

I43. R.v.St., nr. 42.543, 2 april I993, J.T. I993, p. 7I3, noot D. Lagasse. 
deze techniek met de vereiste terughoudendheid en met de nodige voorzichtigheid wordt toegepast. Argument daarvoor is dat de schorsing slechts een billijke wachttoestand beoogt en dat bij de beoordeling daarvan de in het geding zijnde belangen in ogenschouw moeten worden genomen. ${ }^{\text {I45 }}$

\subsection{De cassatiebevoegdheid in het kader van het subjectief contentieux}

\subsubsection{De toepassingsvoorwaarden}

Als administratief cassatierechter doet de Raad van State, Afdeling Bestuursrechtspraak, uitspraak in het kader van het 'subjectief contentieux'. Het gaat om een vernietigingsbevoegdheid die is gesteund op een wettigheidscontrole van een rechtsprekende beslissing en meer bepaald van een beslissing die in laatste aanleg is gewezen door een lager administratief rechtscollege of een orgaan van actief bestuur die een rechtsprekende bevoegdheid uitoefent. ${ }^{\mathrm{I}}{ }^{6}$ Het doel is om een regelende en unificerende invloed uit te oefenen op de lagere rechtsprekende organen. ${ }^{\text {I } 47}$

Tegen een niet- jurisdictionele beslissing van een orgaan van actief bestuur kan geen cassatieberoep worden ingesteld. Beslissingen waartegen nog een beroepsmogelijkheid bestaat kunnen evenmin op ontvankelijke wijze het voorwerp uitmaken van een administratief cassatieberoep. ${ }^{148}$

De bevoegdheid van de Raad van State als cassatierechter is evenwel slechts principieel. De wetgever kan immers de kennisneming van cassatieberoepen tegen dergelijke beslissingen aan het Hof van Cassatie opdragen. ${ }^{49}$

De verzoekende partij moet van een belang doen blijken en moet bovendien partij zijn geweest bij het voorafgaande geding. ${ }^{150}$

Wanneer de Raad van State over een administratief cassatieberoep uitspraak doet, oordeelt hij enkel in rechte.

In het licht van de recente wijzigingen die zijn aangebracht aan de gecoördineerde wetten op de raad van State en mede naar aanleiding van de oprichting van (alweer) een nieuw administratief rechtscollege, met name de Raad voor Vreemdelingenbetwistingen, ${ }^{151}$ lijkt het dat de cassatieberoepen bij de Raad van State aan belang gaan

I44. Zie o.m. J.F. Neuray, 'L'avenir du référé administratif. Considérations sur la loi du I9 juillet I99I modifiant les lois coordonnées sur le Conseil d'Etat', in X. (ed.), Présence du droit public et des droits de lhomme. Mélanges offerts à Jacques Velu, II, Brussel, Bruylant, I992, 686-687; J. F. Neuray, 'La balance des intérêts et la suspension facultative dans le cadre du référé administrative', noot onder R.v.St., De l'arbre en consorten, nr. 48.823, 30 augustus I994, J.M.L.B. I994, I2I5-I2I6; D. Lagasse, 'Le Conseil d'Etat sanctionne-t-il encore la violation d'une règle de forme ou de procédure d'ordre public?', noot onder R.v.St., Union nationale des mutualités neutres en Union nationale des mutualités liberales, nr. 43.835, 27 juli 1993 en R.v.St., Krier, nr. 42.543, 2 april I993, J.T. I993, p. 717.

I45. A. Wirtgen, 'Bespreking van technieken van pragmatisch en billijk conflictbeheer door de Raad van State', l.c., p. 315-3i6.

I46. A. Mast, J. Dujardin, M. Van Damme, J. Vande Lanotte, o.c., p. Io46-Io48.

I47. M. Van Damme, 'De Raad van State als administratieve cassatierechter', T.B.P., 2000, p. 72.

I48. A. Mast, J. Dujardin, M. Van Damme, J. Vande Lanotte, o.c., p. Io49.

I49. A. Mast, J. Dujardin, M. Van Damme, J. Vande Lanotte, o.c., p. Io47.

I50. A. Mast, J. Dujardin, M. Van Damme, J. Vande Lanotte, o.c., p. I050.

I5I. Dit administratief rechtscollege zal onder meer bevoegd zijn ten aanzien van alle persoonsgerichte beslissingen genomen met toepassing van de wetten betreffende de toegang tot het grondgebied, het verblijf, de vestiging en de verwijdering van vreemdelingen waarvoor thans een beroep tot nietigverklaring of schorsing open staat (Parl. St., Kamer, 2005-06, nr. 2479-I, p. I3). 
winnen. Immers, de Raad van State blijft bevoegd om kennis te nemen van cassatieberoepen die zijn ingesteld tegen de beslissingen van de Raad voor Vreemdelingenbetwistingen. Evenwel is, meer in het algemeen, een toelaatbaarheidsprocedure ingevoerd zodat enkel die beroepen die een reële kans op welslagen hebben worden onderzocht. ${ }^{152}$

\subsubsection{De vernietigingsgronden of vernietigingsmiddelen}

Met de inwerkingtreding van de wet van 25 mei $1999^{153}$ werd een formeel onderscheid ingevoerd tussen het vernietigingsberoep enerzijds en het administratief cassatieberoep, anderzijds. De Raad van State doet uitspraak, bij wijze van arresten, over de cassatieberoepen ingesteld tegen de door de administratieve rechtscolleges in laatste aanleg gewezen beslissingen in betwiste zaken wegens overtreding van de wet of wegens schending van substantiële of op straffe van nietigheid voorgeschreven vormen. Hij treedt daarbij niet in de beoordeling van de zaken zelf.

Deze gewijzigde opsomming van de vernietigingsgronden komt er op neer dat met betrekking tot het administratief cassatieberoep geen melding meer wordt gemaakt van de machtsafwending. Er wordt geoordeeld dat deze vernietigingsgrond niet nuttig kan worden betrokken op de administratieve cassatie. $M$. Van Damme oppert in dat verband de vraag of dit standpunt wel voldoende rekening houdt met het disparate karakter van de lagere administratieve rechtscolleges. ${ }^{154}$

De vernietigingsgronden zijn geformuleerd naar analogie met het bepaalde in artikel 608 Ger. W., wat het Hof van Cassatie betreft. Op die wijze heeft de wetgever het optreden van de Raad van State als cassatierechter meer afgestemd op dat van het Hof van Cassatie.

De in het kader van de vernietigingsprocedure opgesomde vernietigingsgronden blijven evenwel voor een deel overeenstemmen met de gronden om cassatieberoep in te stellen, zij het wel dat sommige van die vernietigingsgronden een specifieke betekenis meekrijgen ingeval van cassatieberoep. Zo bijvoorbeeld wat de samenstelling van de rechtscolleges betreft, zullen bepaalde bepalingen toepassing vinden die ook in het gerechtelijk recht voorkomen, zo bijvoorbeeld het verbod voor een rechter om in beroep kennis te nemen van een eigen uitspraak. Vermits het in cassatieberoepen om beslissingen van jurisdictionele aard gaat, zullen de vernietigingsgronden in verband met de procedure, en meer bepaald i.v.m. het tegensprekelijk karakter ervan, een belangrijke plaats innemen. ${ }^{\text {}} 55$

I52. Parl. St., Kamer, 2005-o6, nr. 2479-I, p. 34.

I53. Wet tot wijziging van de wetten op de Raad van State, gecoördineerd op I2 januari I973, van de wet van 5 april 1955 inzake de wedden van de ambtsdragers bij de Raad van State, alsook van het Gerechtelijk Wetboek (B.S., 22 juni 1999). De wetswijziging is er gekomen omdat het cassatieberoep en het vernietigingsberoep bijna niet van elkaar verschilden en de Raad van State de neiging had om zijn controle verder te drijven dan het Hof van Cassatie wat de feitelijke motieven betreft.

I54. A. Mast, J. Dujardin, M. Van Damme, J. Vande Lanotte, o.c., p. 1047 (voetnoot 5).

I55. A. Mast, J. Dujardin, M. Van Damme, J. Vande Lanotte, o.c., p. Io48. 


\subsubsection{De rol van de partijen}

De rol van de partijen vertoont grote gelijkenissen met deze in een vernietigingsprocedure, maar door de eigenheid van het cassatieberoep zijn er ook een aantal verschillen.

De verzoekende partij moet partij zijn geweest bij de door het cassatieberoep bestreden beslissing. ${ }^{156}$ De verwerende partij is niet het administratief rechtscollege dat de rechtsprekende beslissing heeft uitgesproken, maar de tegenpartij van de verzoekende partij voor dit rechtscollege. ${ }^{157}$

Volgens M. Van Damme moet de verzoeker in cassatie blijk geven van een zeker en persoonlijk belang, zonder dat dit evenwel een actueel belang moet zijn. ${ }^{158} \mathrm{M}$. Leroy stelt dat een partij haar belang niet moet verantwoorden, omdat haar belang reeds wordt afgeleid uit het feit dat de partij het geding heeft verloren in eerste aanleg. Deze auteur wijst ook op rechtspraak van de Raad van State waarin wordt aanvaard dat een overheid een cassatieberoep kan instellen omdat deze een belang heeft bij de correcte toepassing van de wet. ${ }^{159} \mathrm{M}$. Hanotiau meent dat in hoofde van een overheid, het belang gebeurlijk zelfs kan bestaan uit een eventueel belang. ${ }^{\mathrm{I} 6 \mathrm{o}}$

\subsubsection{De opdracht van de Raad van State}

\section{Procedurefilter}

Met de recente hervormingen van de Raad van State ${ }^{\mathrm{I} 6 \mathrm{I}}$ is een procedurefilter ingevoegd voor alle bij de Raad van State ingestelde cassatieberoepen en meer bepaald zal een toelatingsprocedure toelaten dat in het begin van de procedure wordt gekeken naar de juridische waarde van het beroep. Cassatieberoepen waarvoor de Raad van State niet bevoegd of zonder rechtsmacht is, die zonder voorwerp zijn, of die kennelijk onontvankelijk zijn, zullen als niet-toelaatbaar worden beschouwd. Artikel 20 van de R.v.St.-wet, zoals ingevoegd door artikel 8 van de recente wet van 15 september 2006, bepaalt dat elk cassatieberoep, zodra het op de rol is geplaatst, en op inzage van het verzoekschrift en het rechtsplegingsdossier, onmiddellijk onderworpen wordt aan een procedure van toelating. Cassatieberoepen waarvoor de Raad van State niet bevoegd is of zonder rechtsmacht, of die zonder voorwerp of kennelijk onontvankelijk zijn, worden niet toelaatbaar verklaard. Enkel worden toelaatbaar verklaard, de cassatieberoepen waarvan de middelen een schending van de wet of een substantiële of op straffe van nietigheid voorgeschreven vormvereiste aanvoeren, voor zover het erin aangevoerde middel niet kennelijk ongegrond is en dat die schending daadwerkelijk van die aard is dat ze tot cassatie van de bestreden beslissing kan leiden en de strekking van de beslissing kan hebben beïnvloed. Worden

I56. A. Mast, J. Dujardin, M. Van Damme, J. Vande Lanotte, o.c., p. I050; M. Leroy, o.c., p. 465.

I57. M. Leroy, o.c., p. 465; A. Mast, J. Dujardin, M. Van Damme, J. Vande Lanotte, o.c., p. I050.

I58. M. Van Damme, 'De Raad van State als administratieve cassatierechter', in T.B.P., 2000, p. 72.

I59. M. Leroy, o.c., p. 409.

I6o. M. Hanotiau, 'Le Conseil d'Etat, juge de cassation administrative', in X, Le Citoyen face à ladministration, Luik, Ed. du Jeune Barreau, I990, p. I32.

I6I. Wet van I5 september 2006 tot hervorming van de Raad van State en tot oprichting van een Raad voor Vreemdelingenbetwistingen (B.S. 6 oktober 2006). 
eveneens toelaatbaar verklaard, de cassatieberoepen waarvoor de Raad van State niet onbevoegd of zonder rechtsmacht is om het beroep in cassatie te berechten of die niet zonder voorwerp of kennelijk onontvankelijk zijn en waarvan het onderzoek door de afdeling noodzakelijk blijkt om te zorgen voor de eenheid van de rechtspraak.

De eerste voorzitter, de voorzitter, de kamervoorzitter of de staatsraad die ten minste drie jaar graadanciënniteit heeft en die daartoe is aangewezen door de korpschef die de afdeling administratie onder zijn verantwoordelijkheid heeft, doet bij beschikking binnen de acht dagen vanaf de ontvangst van het dossier van het rechtscollege, uitspraak over de toelaatbaarheid van het cassatieberoep zonder terechtzitting en zonder dat de partijen worden gehoord. De hoofdgriffier vraagt onmiddellijk na ontvangst van het verzoekschrift het dossier van het rechtscollege op bij het administratief rechtscollege wiens beslissing met een cassatieberoep wordt bestreden. Dit rechtscollege bezorgt het dossier binnen de twee werkdagen na het verzoek tot mededeling aan de Raad van State. De beschikking waarbij de toelating wordt geweigerd, motiveert bondig de weigering.

\section{Kennisneming van de feiten}

De Raad van State oordeelt, wanneer hij kennis neemt van een administratief cassatieberoep, enkel in rechte. De Raad van State moet de door de lagere rechter vastgestelde feiten voor bewezen houden en mag het voorwerp van het voor de lagere rechter gevoerde geschil niet wijzigen. Immers, de lagere rechtscolleges hebben een ruime soevereine beoordelingsvrijheid, wat de aan het geding ten grondslag liggende feiten betreft. ${ }^{162}$ De Raad van state zal daarbij met geen andere feiten mogen rekening houden dan die waarvan het bestaan werd vastgesteld door de met het cassatieberoep bestreden beslissing of door procedurestukken die de lagere rechter zijn voorgelegd. ${ }^{\mathrm{I}} 3$

De Raad van State kan wel nagaan of aan de feiten een correcte juridische kwalificatie is gegeven en of daaruit de juiste gevolgtrekkingen op wettelijk vlak zijn gebeurd. ${ }^{\text {I64 }}$

\section{Onderzoek door de Raad van State}

In België bestaat geen coherente structuur waarbij algemene regels op alle administratieve rechtscolleges van toepassing zijn. Nagenoeg elk administratief rechtscollege heeft een specifieke bevoegdheid, samenstelling, organisatie en procedure. Het gevolg hiervan is dat de Raad van State als het ware genoopt wordt tot een wat verdergaande controle dan die waartoe traditioneel het Hof van Cassatie overgaat. ${ }^{165}$

De Raad van State controleert, in beginsel, op dezelfde wijze de wettigheid van een handeling van een administratief rechtscollege als die van een administratieve overheid. Verschillen tussen beide controles hebben hoogstens betrekking op bepaalde technische aspecten.

I62. M. Van Damme, o.c., p. 7 I.

I63. M. Van Damme, o.c., p. 78.

I64. M. Van Damme, o.c., p. 69-70; A. Mast, J. Dujardin, M. Van Damme, J. Vande Lanotte, o.c., p. Io50.

165. M. Van Damme, o.c., p. 74 . 
De partijen kunnen geen rechtsmiddelen doen gelden die zij niet vooraf hebben onderworpen aan het administratief rechtscollege waarvan zij de beslissing bestrijden. Hierop zijn evenwel uitzonderingen. Met name wanneer vaststaat dat de verzoeker van de door hem ingeroepen onwettigheden slechts kennis heeft kunnen hebben bij de notificatie van de bestreden beslissing of bij de raadpleging van het dossier op de griffie van de Raad van State of wanneer het middel van openbare orde is. ${ }^{\text {I66 }}$

In beginsel kan de administratieve cassatierechter enkel rekening houden met de rechtsvragen die de lagere rechter kon of diende te onderzoeken, b.v. omdat die vragen hem in de vorm van een formeel rechtsmiddel worden voorgelegd, hetzij omdat het onderzoek dat de lagere rechter dient te verrichten inhoudt dat hij zich een oordeel vormt omtrent een bepaalde rechtsvraag, alhoewel die hem niet in de vorm van een afzonderlijk rechtsmiddel door een partij is voorgelegd, hetzij omdat het gaat om een rechtsvraag die de openbare orde aanbelangt en door de lagere rechter ambtshalve dient te worden onderzocht. ${ }^{\mathrm{I} 67}$

4 De middelen van openbare orde en het ambtshalve aanvoeren van middelen

Zoals in de vernietigingsprocedure kan de Raad van State in een administratief cassatieberoep ambtshalve middelen opwerpen.

\section{Substitutie van motieven}

De Raad van State zal, wanneer hij optreedt als cassatierechter, vlugger overgaan tot een substitutie van motieven en zal hij een ondeugdelijk motief van de met het cassatieberoep bestreden beslissing kunnen vervangen door een deugdelijk motief om ermee het beroep te verwerpen.

Dat de Raad van State minder terughoudend is kan worden verklaard in het licht van het principe van de scheiding der machten. Bij het cassatieberoep bestaat immers niet het risico dat de Raad van State zou moeten worden geacht in de plaats te treden van het bestuur. ${ }^{\text {I68 }}$

\subsubsection{Draagwijdte van de vernietigingsarresten na cassatieberoep}

De beslissing waarbij de Raad van State uitspraak doet over een administratief cassatieberoep, geldt slechts inter partes.

Wanneer een jurisdictionele beslissing vernietigd wordt, dan moet zij normalerwijze worden vervangen, tenzij vaststaat dat het betrokken rechtscollege van het geschil geen kennis kon nemen, b.v. wegens onbevoegdheid of laattijdige indiening van de aanvraag. Behoudens dat geval, verwijst de Raad van State de zaak naar het rechtscollege dat ten gronde uitspraak zal doen. Dit rechtscollege is in beginsel het rechtscollege dat de vernietigde beslissing nam. Het gebeurt dat een bijzondere wet de verzending naar een ander rechtscollege oplegt of naar hetzelfde, maar anders samengestelde rechtscollege.

I66. A. Mast, J. Dujardin, M. Van Damme, J. Vande Lanotte, o.c., p. I05I.

I67. M. Van Damme, o.c., p. 7I.

I68. M. Van Damme, o.c., p. 72. 
Het rechtscollege waarnaar de Raad van State verwijst is van rechtswege gevat door die verwijzing in het arrest. Het rechtscollege zal opnieuw over de grond van de zaak uitspraak moeten doen en zal, met het oog daarop, het geschil in zijn geheel aan een onderzoek moeten onderwerpen. Partijen kunnen andere middelen opwerpen. ${ }^{169}$

Het rechtscollege waarnaar de zaak verwezen is, moet zich gedragen naar het vernietigingsarrest van de Raad van State ten aanzien van het daarin beslechte rechtspunt. Het rechtscollege dat deze regel miskent, schendt het gezag van gewijsde van het cassatiearrest en de betrokken beslissing kan om die reden worden vernietigd. ${ }^{170}$

\subsection{Bijkomende observaties}

\subsubsection{De balie}

Hoewel de Raad van State niet rigorist is ten aanzien van de wijze waarop de feiten en de middelen moeten worden weergegeven in het verzoekschrift, doet dit geen afbreuk aan het feit dat een aantal formaliteiten desalniettemin moeten worden nageleefd. Zo zal elk verzoekschrift moeten zijn ondertekend door de verzoekende partij of zijn advocaat. Wat deze laatste betreft, wordt opgemerkt dat er in de schoot van de Raad van State geen afzonderlijke balie bestaat.

Ten tijde van de oprichting van de Raad van State werd overwogen om een bijzondere balie op te richten, ${ }^{\mathrm{I} I \mathrm{I}}$ net zoals er een balie van cassatie bestaat. De wetgever verkoos echter om alle advocaten toe te laten de partijen bij te staan of te vertegenwoordigen, op voorwaarde dat ze reeds tien jaar waren ingeschreven op het tableau van de orde.

Deze laatste voorwaarde werd evenwel geschrapt in $1952,{ }^{172}$ zodat alle advocaten die ingeschreven waren op het tableau van de orde bevoegd waren om de partijen bij te staan en te vertegenwoordigen voor de Raad van State, evenwel met uitsluiting van de advocaat-stagiair.

Deze uitsluiting kon, mede in het licht van de door de universiteiten georganiseerde bijzondere opleidingen in het administratief recht, evenwel niet worden verantwoord. In I998, heeft het Grondwettelijk Hof geoordeeld dat de uitsluiting van de advocaat-stagiair discriminerend is. ${ }^{173}$ Bijgevolg werd de R.v.St.-wet in die zin aangepast door de Wet van 25 mei 1999.

Heden ten dage bestaat er geen enkel beletsel in hoofde van de advocaat(-stagiair), om voor de Raad van State te verschijnen.

I69. A. Mast, J. Dujardin, M. Van Damme, J. Vande Lanotte, o.c., p. I05I.

I70. A. Mast, J. Dujardin, M. Van Damme, J. Vande Lanotte, o.c., p. I05I-I052.

I7I. Pasin., I946, p. I2I7.

172. Wet van II juni I952; M. Leroy, o.c., p. 542.

I73. Grondwettelijk Hof nr. 55/98, 20 mei 1998. 


\subsubsection{De achterstand}

Veel van de wijzigingen die de voorbije jaren zijn aangebracht in de R.v.St.-wet en het Procedurereglement zijn ingegeven door de bezorgdheid van de wetgever om de achterstand in het afhandelen van beroepen in het objectief contentieux terug te dringen of minstens binnen de perken te houden.

De redenen zijn deels toe te schrijven aan ontwikkelingen in het verleden, doch ook aan het algemeen gegeven dat in onze moderne rechtsstaat de burger mondiger is en sneller geneigd is om zijn rechten voor de rechter af te dwingen. Ook is, als gevolg van de toename van de regelgeving en de niet steeds gelijkmatige kwaliteit ervan, het aantal potentiële conflicten met de overheid toegenomen. Bijgevolg is er bij de Raad van State een toename van het aantal kortgeding procedures aangezien deze ongetwijfeld tot een meer efficiënte rechtsbescherming bijdragen. ${ }^{174}$

In samenspraak met de Raad van State werden overheidsmaatregelen genomen teneinde hieraan te verhelpen. Deze maatregelen zijn van proceseconomische, organisatorische en institutionele aard.

Als maatregelen van proceseconomische aard kunnen bij wijze van voorbeeld worden vermeld, het instellen van verkorte procedures bij kennelijk onontvankelijke, kennelijk ongegronde of kennelijk gegronde verzoeken, de toelaatbaarheidsprocedure voor alle cassatieberoepen, de veralgemening van de alleenzetelende rechter, de indiening van een enige akte,...

Als maatregelen van organisatorische aard kan bij wijze van voorbeeld worden gewezen op de verhoging van het aantal staatsraden, de opheffing van de bevoegdheid van de Raad van State om kennis te nemen van individuele beslissingen in het vreemdelingenrecht, het invoeren van technieken van modern management hetgeen gepaard gaat met statutaire wijzigingen.

Als maatregelen van institutionele aard kan worden verwezen naar de verplichting van de Raad van State om elk jaar, in de loop van de maand september, onderzoek te doen naar de stand van de zaken die hangende zijn bij de Raad van State en hierover verslag uitbrengen bij de Ministerraad. ${ }^{175}$

I74. G. Debersaques, M. Van Damme e.a. (ed.), Rechtsbescherming door de Raad van State. 15 jaar procedurele vernieuwing, Brugge, Die Keure, 2004, p. I3-I4 en 17.

I75. Artikel I20 van de gecoördineerde wetten op de Raad van State. 